\title{
WELLES
}

Epithelial Degenoration,

Regeneration \& Secretion

In the Mid-Intestine

of Collembola

Entomology
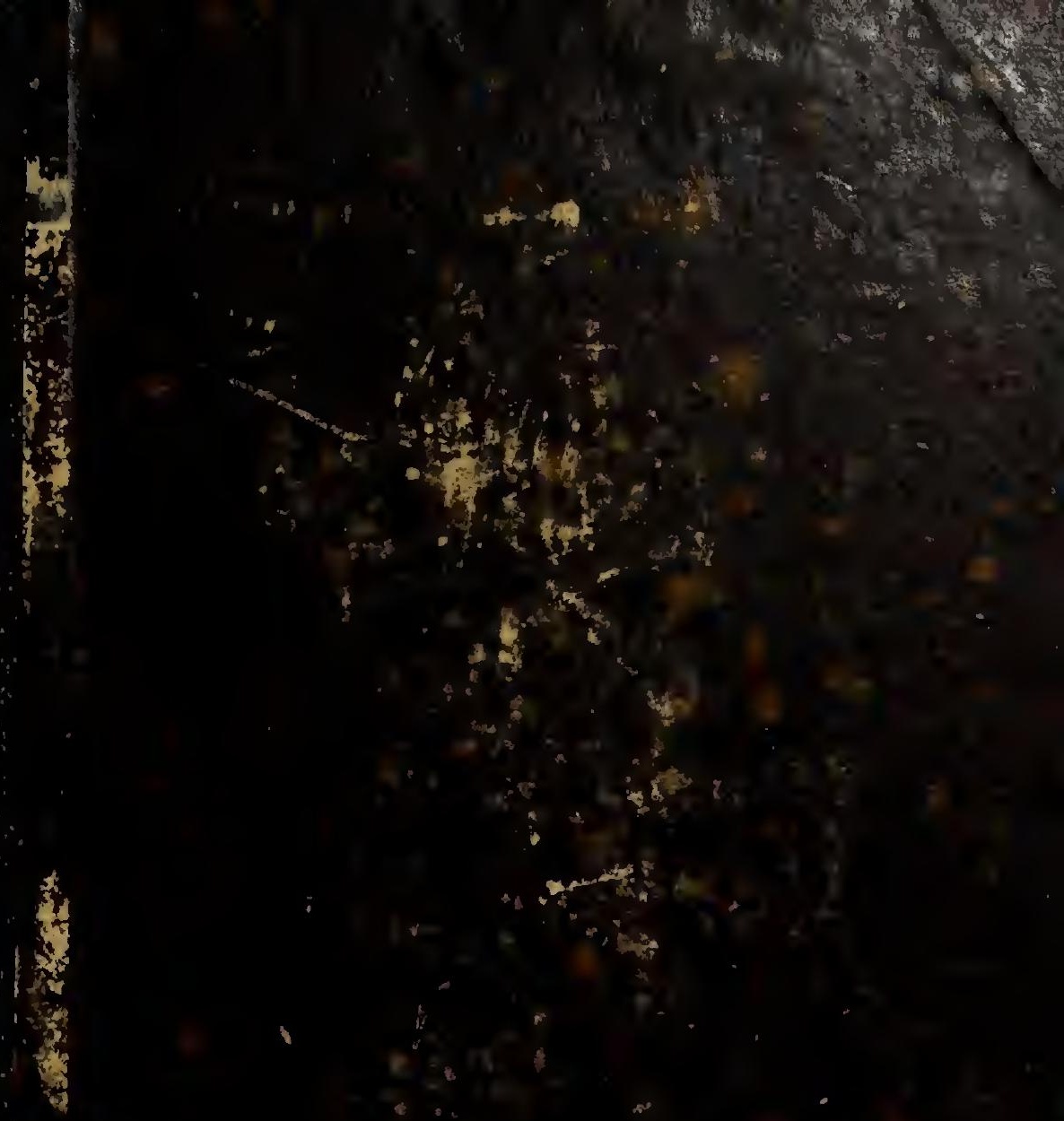

A. M.

1904

,

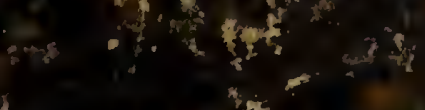

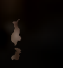
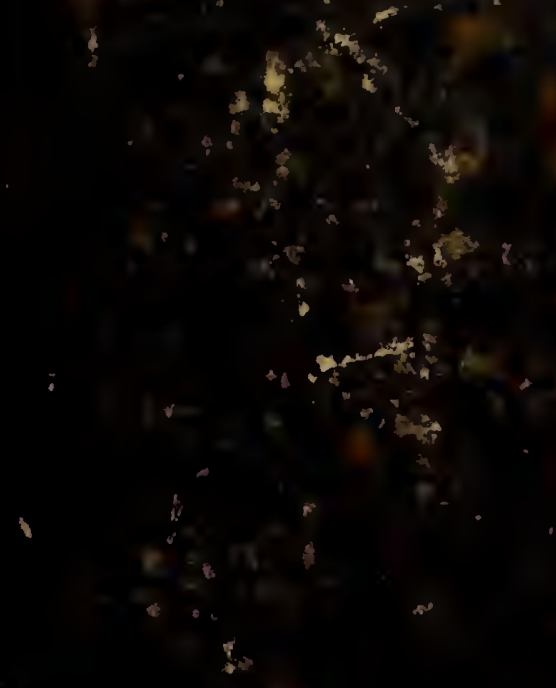

k
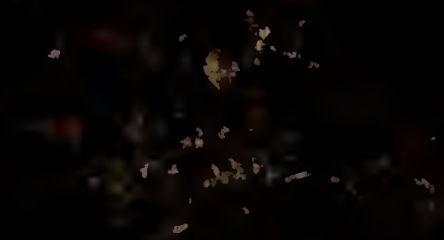

ขWIVXXST 
UNIVERSITY OF ILLINOIS

WAS 190 
Digitized by the Internet Archive in 2013

http://archive.org/details/epithelialdegene00well 


\section{EPITHELIAL DEGENERATION, REGENERATION AND SECRETION IN THE MID-INTESTINE OF COLLEMBOLA}

MIRIAM URSULA WELLES, A. B:, 1903

THESIS FOR THE DEGREE OF MASTER OF ARTS IN ENTOMOLOGY IN THE GRADUATE SCHOOL

UNIVERSITY OF ILLINOIS

1904 

1904

W. 45

UNIVERSITY OF ILLINOIS.

may 27

1904.

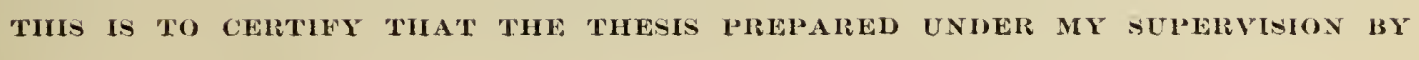
Aninam Cunca inales

Extrter Ufithiciel begunation, Regmation, and zuchution in the onide Anturtine of Cullombola

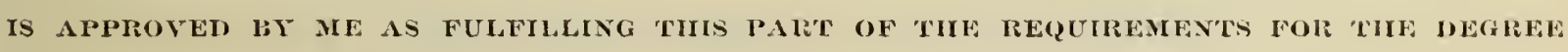
or master of ant.
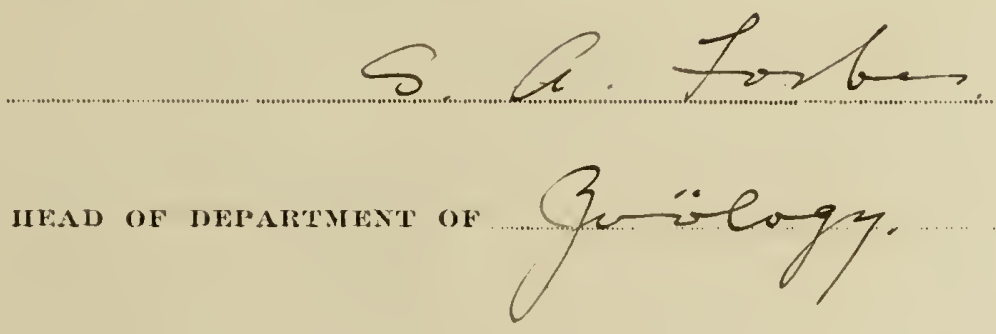

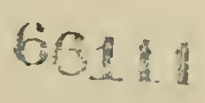



EPITIELIAL DEGEIERATION, RTGEITERATION AID SECPETION IN THE IIID-IUTPESTINE OT COLLEIBOLA.

MIRIAM U. MELLES.

COMTEITS .

I. Introduction............. I.

II. Raterial and liethods........ 2 .

III. Alimentary Tract.......... 5 .

IV. Degeneration.............

V. Regeneration................

VI. Secretion................

VII. Conclusion..............24.

VIII.Surnary $\ldots \ldots \ldots \ldots \ldots \ldots \ldots$.

IX. Bibliography...............

X. Explanation of Plates........31.

XI. Plates...................... 



\section{INTRODUCTIOH.}

This paper deals chiefly with a remarkable process of epithelial degeneration which occurs periodically in the collembolan stomach and has un important physiological significance; and deals secondarily with regeneration and scoretion in the stomach of Collembola as compared with those functions in other insects.

The details of this process of dergeneration are here described and interpreted for the first time. The only previous references to the subject are by Sommer ( $\left.1355^{p .713}\right)$, who mentions that he founc. tro different aspects of the epithelium of the midi-intestine of Iomocems (Macrotora), and by Fernald ('00, p. 455), who makes a brief reference to the process as observect by hir in Anuridi maritima.

The work has been done under the supervision of Dr. T. W. Folsom, to whom I am deeply indebted for constant and valuable advice. 



\section{IATERIAL AID IIETIODS.}

The species of Collembola usea in this study were Tomocemas niger, Podura aruatica, Isotoma viridis and orchesella cincta.

By examining large numbers of Tomocems, I was able to obtain a sufficienty complete series of stages in the degeneration anc regeneration of the stomach epithelium. It mas unnecessary to have as complete a series in the case of the other species, since they vere found to proscnt essentially the same conditions as Tomocemas, Whence I am led to believe that the phonomena as doscribec here for Tomocerus are the same in all Collamola. Specimens talien at ranciom and sectioned showed striking differences in the condition of the stomach epithelium. In order to ascertain what relation, it any, existec between the condition of the stomach epithelium and that of the external intesument, it was necessery to kizl the insect with lmown reference to the time of the external moult. To this end a large number of insects were collected and put, singly, into small glass tubes, with bits of moist, decired wood, for food, the tubes being closed by cotton plugs. When proper precautions were taken, including the use of sterilized cotton and distilled water, to prevent the gromth of fungi, it was founci that the insects could be kept alive for three or four reelss, and their habits of feeding, moulting, etc., readily observed.

Collembola moult throughout life, continuins, to moult astar they are full grom.

This fact, already noticed by Sommer, is or spocial significance, as indicating that ecdysis is hone, at lecist, something, 

more than a provision for growth. In collembola, it docs not depend upon temperature or lack of food, and may prove to be in excretory process in these forms, which are unique anong insects in having no lialpighian tubes, notwithstanding the statement of Nicolet ('4l), Tullberg ('72), and Sormer ('85).

The interval betwe n two successive moults increases with the are of the individuil. Very young insects moult as often as every two days, while aciult specimens moult at intervals varying from six to eight days. For some tire (about twenty-four hours) previous to moulting the insects are inactive, and tike no fooc, but i.mediately after ec dysis the insect usually devours the cast skin,-- a habit which necessitates almost constant observetion in order to detemine the time of the moult, before the exuviae have disappeared. The eat on skin, with its numerous chitinous scales, may easily be recognized in the stomach of the insect, and these remains are of use as indicating wien the last moult occurr.

The material vas studied by means of microtone sections whi In dissections, made under the compound or dissecting microscope. Usually, sections of the entire insect rere made, but often the stomach was dissected out, ana then sctioned. Either mothod cuve excellent results, but the littor is the better, theoretically, as regurcls fixation, orientation and ease of sectionine. The stmicural conditions in fixed. and stained material vere compared critically with those in the living cytoplasm, which ras obtained by dissecting out the stomachs of decapitated insects. Both preserved and living cytoplasm agreed precisely in structure, so fur as it was possible to observe. The living cytoplasm is alveolated in the scme manner as the prescrved cytoplasm, -an importiunt fact, 

Since the transformations in the epithelium of the storach are lancely changes in alveolation, as wy ficures show.

For killing and fixing the tissues, I used, with excellent results, a saturated solution of mercuric chloride in thirty-five per cent. alcohol, with two porcent. of glacial acetic acid. This solution was used at a temperature of about $20^{\circ} \mathrm{C}$, and allored to act for three or four minhtes, after wich the tissues rere left in seventy per cent.alcohol for twenty-four hours in order thoroughly to remove the mercuric chloride. For embeding, the usual paraffin method was employed, using watch glasses, as being most convenient. Serial sections were cut, with a "linot-Zimmemann microtome, from $02 / 3$ to 10 micra in thickness, in sucittal and trunsverse planes.

Dissected raterial was stoincd in toto, irmediately aftor washing out the fixing arent, Grenacher's alcoholic borax-currine being used in this case. The tissues were left in this stain for twenty-four hours, then decolorized in alcohol of screnty pen cent. acidulated with a few drops of hidrochloric acid, until a cleur, bright red color was obtuined.

For staining sections, Ehrlich's acic haomotoxylin was no ed, alone or vith safranin or orange $G$. The tissues vere stained in the haematoxylin for about ten minutes, then decolorized in slicllt acidulated alcohol, one or tro minutes, or until they showed cood differentiation. In double-staining, the tissues vere troator as above with haematoxylin, and counter-stained in a reals solution of safranin in absolute alcohol, or else a dilute solution of orango G. In ninety-five pei cent.alcohol. Both safranin and orance $G$. are excellent chitin stains. The best results as recurcis precision 

and runce of difforentiation were obtwined ith Frrlich's hueratonI in and oringe $G$.

\section{III.THE ALIMENTARY TRACT. (PI. I, Fi@. I).}

In Collembola, and Thysanura (especially Campoded and Japy*) the alimentary tube prosents primitivelit simple conditions, such as in the less prinitive insects (Pterygota) are confined to the e.es or lamva. In Tomocems, as in all other elongate collembolins, the cipestive tube is axial in position, extends dinect: from the mouth to the anus, and falls into the thee distinct, rogions, narnoly, fore-intestine (TiG. I, f. inth), comprising morth, phanrnx and oesophagus, and derived from the ectoderral stomodacur; mid-intestine $(\mathrm{m}$. int, ), from the enciodomel mesenteron; wnd Iincintestino, (h. int), from the ectoderral proctocacum. Thene ane no diventicula excopting the siuivary oluncis. The posterion che of the oosophamus folcs into the stomech to fom a cardicic vilve, (c.m.) and at the posterior end of the stomach a pyloric valvo(prl.) occurs. The anatomy of the entire digestive tube need not defain las, since it has alreacy been described by Tullberg ( 172$)$, Sommer ("5),

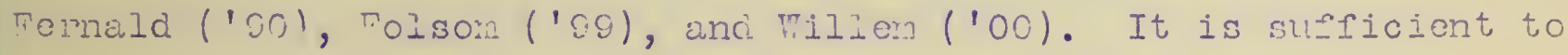
say thut the mall of the tube consists of a single lanerof opithelial ceils, which s:creto ontilly a distinct intim: ( 1 in.), and ectally a delicate, hyaline, homogeneous hasement me.brane, or tunica propria (b.m.). This is sirrounded by a single laver of

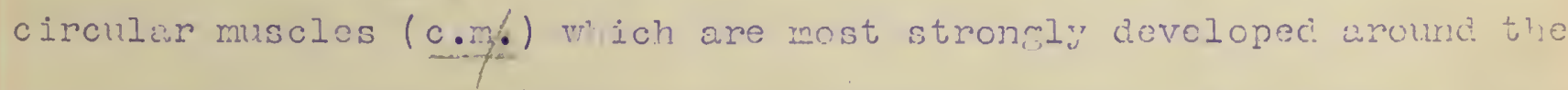
pharynx and rectur. Outsicle the circular ruscles is a single liwer 

of longitudinal muscles $(1 . \mathrm{m} \cdot)$ in the case of the stomch; but tile $\lim$ absent around the oesoplasus and roctum.

The mid-intostine, otherrisc in wh ws vontriculus, chulific stomach, or stoment, [this tem is in current use, wnd is oft:n convenient to emplo", nroviced it, be unciensouci tli..t the storauh of an insect is entirely different, physiologicallÿ, from the stom ch of a vertebrite] is the principal civision of the culimentiry tract. In the adust insect (Tomocemis) the mid-intestine is ebout two willinetens in lenritn, reaching from the begining of the mesothorw: to the fourth ibdoninil iscguent. The wVerare diameten is wbo... one hundroc micria. The ventriculus is surrounciea, immediately by about ninet: circular mascles, and next by cbout sixteen longitudinal muscles; both kinds of nuscle-fibersare distinctly striated. As these muscles undergo no morphological changes in the wdut ins?t, they will seldom be rofemed to rupo. I not pass to a considemtion of the complex changes undergone bi the epithel-al cells. These chanfes cre, of course, continuous, but may for convenience of description, be referred to five stames.

\section{IV.DEGEMTERAT IOMT .}

$$
\text { stige I. (PI. 2, Fis. 2). }
$$

The degeneration of the opithelium of the stonach occuss only at each moult, anc then occlipies but one or two days, at mest. At all cther times, i.e., betreen molits, the epithelium is in what I may tem a resting condition, since it is chiracterizcd b" tile absence of muciea civision, though the epithelium is. of corrse, active so far as secretion und absorption are concerned. 

In the resting condition, there is, co has been saic, a sing, e layer of cells; these ure now colurnar (Tig.2), and hexactonal in cross-section, (PI.2, Fig.3); the averace length of each cell is about eighteen micra, and the width, four to six micru.

The cytoplism has, under low magnification, a sornewhit granular ap eurance; under a one-tenth horogeneous immersion-objective, hovever, a finelr alveolar structure appeurs. This is due to round or oval vacuoles or alveoli (Fig.2, alv.), containing; a nonstainable fluid, and separated from one another by a stainable substince which appears in section as a reticulum. Precisely t?e same appearances are given b: the living cytoplasn of these colls. In sectioned ind stained raterial the reticulum frequenty prosents a sugsestion or $\approx$ cranulur structure, not sufficientir cistinct, however, to be represcnted in mi ficumes. Around the nucleus, the cytoplasm is less dense than elscrkere, owing to a coarser alveolation (Fieg.2). The cytoplism becomes somewhat densen toward the inner half of the celi, i.e., toward the intina.

Adjoining celis are separated by cell walls(lat.), though treso are often indistinct und incomplete, in which case the colls are usually distinguishable from each other ondy by differences in tre density of the cytoplusm and by the positions of the nuclei. The dividing rall is usually most distinct toward the base of the cell. It has not the appearance of a sceretion, but rather that of a condensation of the ordinary reticular substince. It stains in the sume ray as does this inter-vachirar substance in. other parts of the cell, but somerhat more deeply, being, therefore, denser. The appearance is exactly what would result if lateral prossure, cue to turgidity, exertec radialiy in each cell, werc to cause conciensation 

at piane

alowg the $\wedge$ Ifre of the cell wall, whore tho pressires from opposite sides rould neet.

The fact that the inter-cellular boundaries wre often incomplete or indistinct, was noticed by Fernald ('00, p.430), who was inclined to attribute it to poor presemition. I am satisfied, however, that this incompleteness of the side-walls is a nomi condition, as my material in which it occurs is in an excellent, state of preservition, - showing distinctly the minute alveolation of the cytoplasm.

The nucleus ( $\mathrm{n} d)$ is situated near the center of the basal half of the cell. It is rounc or ovil, wh the lons axis in the lonsitudinal axis of the cell, and measures from four to six micra in diumeter. There is a distinct nuclear membane. The karyoplasm, as Nell as the chromatin matter, takes the haematoxylin stain much more deeply than does the cytoplasm, becoming dark blue anct the chromatin blue-black; while the cytoplasm remains pale blue or takes the contristing, color, if a second stain is used. Iumcrous chromatin bodies (chr.) and wavily a nucleolus (nl.) are present in each nucleus.

Scattered irregularl" through the cytoplasm are small round concretions (conl) of various sizes up to one micron in diameter; they are hichly refractive, non-stainable, and consist of concentric layers. Except in being smiler, these concreticns cure precisely similar in appearance to the large pseudo-crystals found deposited in the fat-body. The latter have been described and ficured by somer ('85, p . 689), who found them insoluble in water anci alcohol, but soluble in reak acids with a livel: evolution of Giss, and concluded that they were calcium carbonate in combination 

with some orgunic substince. Temeild ('90, p . 442) Tomking on Anurica ranitima, fonnci sinilur concrotions in tro indivicuals, ance concluded that in the rest of his material they had been dissolved by the acids used in tixing and killing.

Viliem (100, p. I0I) described the same structures is found in sminthurus fiuscus: "Les concrétions que loçent les vacuoless des collulos en question sont sphéroïdaies, de taille fort variable, nettement constituées de couclues concentriques et conséquenmont formées par dépôts successiês autour d'une masse initicule. Insoluble dans l'eau, I'alcool, l'éther, le chlorofome, elles disparaissent dans les acides étendu.s. Lorsqu'elles sont prticulièrement nombreuses, come chez Smintmus fuscus adulte, leur destruction par une petite quantité de liquide ucide s'accompagne de l'apnarition de masses cristallines irréculières qu'on voit s'accrô̂tre rapicement sous le microscope; celles-ci prósentent par leur aspect, par leur solubilité ou insolubilité rospecuiv: dans divers réactifs, tous les caractères de l'acide urique. La réaction de la murexide s'obtient d'ailleurs aisément avec dos eragnents appropriés de Sminthure. D'autre part, si l'on attaque pur l'acide chlorhydrique étenclu des anas concrótionnaires du même collembole, on obtient une solution qui, lentement évaporée sur un slicie, foumit des cristaux appartenant au systène cubique et identiques à ceux du chlorure de sodium."

As the result of my own experiments, I have found that the concretions in the epithelium of the stomach and those in the futbody behave alire, when treat with water, hydrochloric acid, picric acid, caustic potash, alcohol, $x_{i} l o l$, etc. Both rincis are insoluble in alcohol and xylol. Arter soaking for some time in wator, 

the concretions assume narly the sure index of refraction as the water, so that they become almost imvisible. Prolonged treatmont with oithor acid cild not dissolve the peripheral zone, but the cartral part, which had been more crunular, disappeared and rast have dissolved, since it conld not be recovered in the sme forn. Treatment with caustic potash for several hours caused the concretions to disappear as such, leaving only pale circular outlines and in some cases, minute granilar residues which had formod the nucleus of the concretion.

Notwithstunding Willen's statement that the murexide reaction is casily obtained from the coneretions in the fat-body, I failed to get the reaction from either lind of concretions. I did obcain needle-shaped crystals from a hydrochloric acid solution, but am not certuin that these came solely from the concretions. Crystals obtained from a picric acid solution of the concretions were needle-shaped and slightly curved, often branching fun-lite at one end. These were incistinguishable from crystals of sodic picrate, which I obtained from Nacl. Thus the base of the concretions is sodium; as rogiras the acid, my partiy negative results, I admit, have less weight than the positive results of willem; inded, from my orm experience, I am inclined to arree rith him that the concretions are socilc urate.

The chemicul tests us a by Willen are the sure ones by meins of which Plateau ('74, p. 32) obtained sodic urate from the Malpighiun tubes of Carabus auratus anci oryctes. Tabre ('jo), it may be mentioned, found uric concretions in the mid-intestine of ophex. Within the dicestive cavity of each of the spocies exumincd, it is common to ind numbers of spheroidal bodies

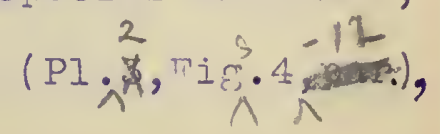



varying in dimeter from ten to founteen micra. They have an alveolated citoplasmic stmicture not unlike that os the epitheliur, and possess the parts of a typical cell, i.e., nucleus $(\not)$, nucleolus (n). F and a distinct nuclewr membrane (n.m.). The nucleus siains more deeply than the rst of the body, and shors distinct chrometin elements (cmr.). These cells are foind in all parts of the digestive cavity, on either side of the peritroplic membrane, sni also within

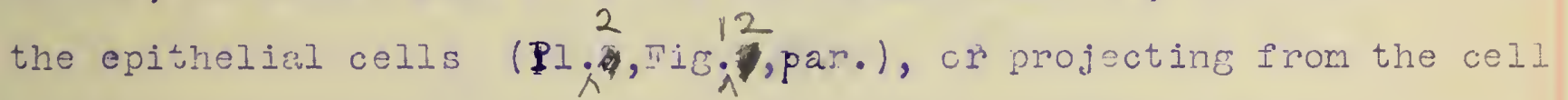
as if in the cuct of passing into the lumon. In the resting cells they may be found on either side of the nucleus, or evon wedged between two of the epithelial cells.

These free cells are ovidently parasitic, unicellulin organisms, probibit graganines. Sommer ("85, p. 715) made the follning obsarvation: "Überaus hëu=ib, ja fast als konstanter Parasit findet sich im Chylusciam eine Gregarine. Dieselbe tritu entwedor vereinzelt auf, odcr gesellig, zuweilen in solchen liassen, dass statt des Darmepithels fast nur Gregurinen an der Dammanc. vorhanden zu sein scheinen, welche mit der Kopfe in die Zellen eingefrassen, dicht an einander gedränst fast ausschilessich cien Inhalt des Damnes ausmachen. - Zuweilen fand ich auch ausserhalb des Dames, im genzen Korper dicht angehauft Pseudonavioellen ähnliche Gebilde.

"Fben so hat,te ich Gelegenheit, Entwicklungsstadien von Cestoden, Cysticcrken, zu fincien, welche den aus dem Darm von Tenebrio molitor von stein beschriebenen sehr fleichen.

"Fndich ist das Vorkommen junger Nematoden au crrähnon, welche spirelie zusamengerall, gelegentlich in mehrefacher zahl anjetroffen vurden." Sommer neither figures nor describes the forms 

to which he refers as parasives; I huve therefore no way of ascertaining whether or not the organisms which I hive observed are the same species thit he found. Ify material, as it happened, contained no Cysticerci or Nematodes.

The intima or lining mombrane, is a secretion frou the epithelial cells of the stowach. It is striatod thansverselu, the striae beinc fror oneto one und one-half micra apart. They are due in all probability to minute pore-canils through which fluids may be either secreted or absorbed. Trenzel, Oudemans, Sommer, Gehuchten and others have cescribed and figurec the intina as a laven of fine filaments, to which they give the name "Iïirchensaum". In Tomocems, however, the intima prosents no such appearance, but is clearl: a membrane $(\mathrm{PI} \cdot 3 / \mathrm{T}, \mathrm{I} \cdot 16)$. The thickness of the intima in aifsarent individuals varies from that of a barely perceptible line, to a thickness of four micra.

The food-contents (PI. $/ 4$, Fis. 16, food) of the storach are always enclosed in a thin, olastic membrane (per. m.) which holds the substances together in a corpact, cylindrical mass. A similar peritrophic membrane, or "funnel", has been described by schneider ('37, p. 140), as occurring in Thysanura and in many higher foms, such as contain Coleoptera, Diptera, and Iarvae of Lepidoptera. Schneider observes that "Alle den Trichtor besitzenden Insecten (und Larven) fressen feste, selbst unverdauliche stoffe, während die anderen, flüssige Nahrung zu/sich nehren ."

Various sugestions as to the origin of the peritrophic membrane have been made. Pagenstecher (as qroted by schneider, p.140) regarded it as a secretion of the silivary glands. IJo evidence to support such a view is foland in the forms I hive exanined, inc the 

conception of a tube fomed mithin the stomah, fror the secretion or clands in the head, appeurs to me, to suy tho least, improbable. listschnikoff (as quoted by cohneider, p. 110), oudemans (p. 191), and Schneider (p. 140) state that the peritrophic tube is chitinous, a statement which does not apply in the case of Collembola, for I find, upon treatmont with caustic potash for soverel hours, theit the food-enclosing nembrane, as well as the intima of the midintestine, disappears, while the chitinous intima of the fore-and hind-intestine ${ }_{\wedge}$ unaffected visibly by the reagent. Plateau and Balbiani (quoted by Packard, p. 314) offer a more reasonable explanation, namely, that the nembrane is a secretion formed at the surface of the epithelial cells of the chylific stomach, and this I Iind to be true in collembola. In almost any specimen, the oricin of this membrane around the food may be seen(PI. $/$, Tig. $(8)$. The intima either splits or else loosens from the opithelium and envelops the food-mass, at the same time losing its striatec appearance, und becoming roldea ond tristed in accomodating itself to the size of the food-mass when tie lattor coes not ill the lumen. After losing the intime in this ay, the epithelium immediately begins to secrete another, which increases in thickness as secretion proceods.

The food (PI.I, Fis.1; PI.4, Figh, food) contained in the peritrophic membrane consists mainly. of particles of wood, and in miny cases, of fungus spores. Three kinds of fungus spores vere cound repeatody in different specinens, ofton in auch quantity as nearl:. to fizl the aigestive cavity. These were recognizable as capnodium salicinum, liacrosporium and Triposporium, the last two not being sufficiently intact to admit of specific detemination. (For the 

determination of these fungi, I cur indebted to lir. J. T. Burrett, of the Univonsity of IIIinois.] In the food mass are found also spliemical or elongrive bodies (par.), each possessinf a nucleus, nucleolus and numerous vacuoles, which bodies appear to be identical with those before described as embedded in the epitheliun, and as beinê probably greçarine parasites.

In the stomach cavity and cutside the peritrophic mombine there is usually a faintly stwining, cvonly grunular substance (pl.) sinilar to the blood-plasma found in the body cavity, but contuining no corpuscles nor nuclei. This substance is probably a digestive fluid secreted by the epithelium of the stomach.

$$
\text { Stace II. (Pl.4, jig. 17) }
$$

An insect killed about forty-eight hours be fore ecdisis, exhibits the following modifications of the epitheliur. The alveolation has become sornewhat coarser, which brings about in increase in the length of each cell anc consequently in the thickness of the whole epithelial vall. The hichly refractive granuies, or concretions (con.) in the cytoplasm become more numerous, especially in the regicr between the nucleus and the intima.

A series of impontent cranges in tre epitreliur now occurs. These changes are continuous and rapid, and the entire series is completed by the tine tre extemal monlt takes place. Fron this stace until the next restine stare, the side walls(lat.) of the cells are incistinct, except occasionally for a short distunce necur the base, the cells being distinguished from one another only b: their nuclei und by differences in density. 



\section{stace III. (PI. $\left.\stackrel{4}{t}, 19^{19} \cdot f\right)$}

The thichness of the epithelial wald is now from thinty-sir to forty micra, -an enormous increase as compared mith its thickness in the resting stace, - and the inner half of the cell shovs numen-

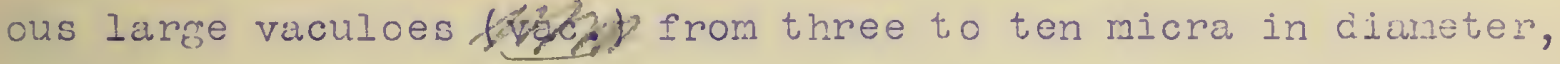
many of which contuin conspicuolus corcretions (con.). A cistinct rot of vacuoles, (vaci) tor to six micra in ciameter, is found immeciatel. beneath the intima (in.). The gregarine parasites (par.) are now found in the ental half (ent.) of the rall, and in most cases, each is surrounded by a clear vacuolar space.

The most striking difference, horever, between this stace anci the procepding, is seen in the position of the nuclei $(\mathrm{m} \cdot \mathrm{g})$, some of thich have moved from their oniginal posision in the newal half (ect!) of each cell, to a new position in the more coarsely vacuolated area (ent!) nearer the lumen, forming a second layer of nuclei, inside the oricinal, or primarr, laver. The number of micrant nuclei (mis. n.'), is sowewhat less thir tie number of remaining nuclei, being about corty-trree per cont. of tho whole number. It is noticeable in sorne cases that each of the micrent nuclei is entirel; surrounded by larce vacuoles, us it moves from the basal to the ental half of the cell. But what moves the nuclei? I believo that this nuclear migration is to be explained in teams of coll-vacuolation, the changes in which have been followed closeig in this study, as appears in the figures given. Immediatoly after the nuclear civision which took place g.t the prece ding ecd"sis (as described berond), the two daughter nuclei remain neir eacl: other, thourh separased bu a cell-wall. The plane of division is such an to lecve one of the claughtin malei sonerlut nower the 



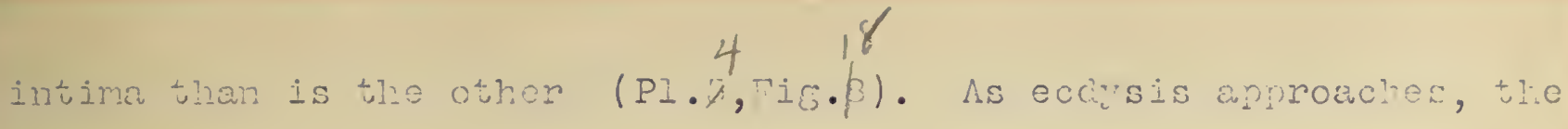
inner half of the crtopiasmic layer becomis less dense tian tive outer half, oring to the distention of its alveoli and vacuoles, and the dackter nuclei which are neaner this moricr of lessen consity, move into it. This movernt is accounted for by the tursicity of the citoplasm. When a cell of the stoinach opithelinm is isolated, in its omn fluid, without the addition of waten, it swells to a shemoidul form, owing to its turgiditu (Frenzel, p.rst, Tab. 7, Fic. 8; Oudeman s, p. LEO, Tab.III, fig. 36), anct this sine quality seems to explain the populsion of a nucleus from a region of greater density to one of lesser density. It oxplains cur well, the removil of gregirines from the cells of the stomach, and alsc the removal of excretory concretions (as described berond) from tie same cells.

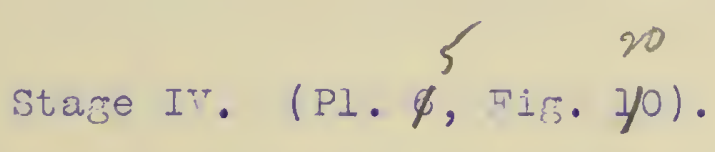

Following the condition described above, a separation appears between the denser, basal part (ect) of the epithelial rall anc the more coarselir vacuolated portion (ent/) next the luren. Plio sepurcition is effected by a dividing membrune (in/) which forns midray between the intirna and the basement membrane. This dividing Wull is at first extrone $y$ thin, but it gracually incriases in thickness, and acquirss all the appearunce of the oncinary intina. As it wrows in thickness, it pushes beror? it tre vicuolatec entul civision of t: e rall.

mlee number of nuclei (n.) $_{\text {. }}$ remaining in the prima: position, i.e., neir tive basement membrune, is now restored to the nomal number by mitotic civision. Since the number before this division 

is rathew more than half the oricinal number, wa since the number of cells in the asuing epithelium of the acilt insect does not increase from moult to moult, it follows shit not wll the nuc set left belind divide, but onlj enoumh to replace those rhich were lostto express it in this way. In the growing insect, noweven, theme occurs an actial increase in the nurbor of epitheliwl cells. The nuclear division is indirect or mitotic, ds was said. Imreaiatel:

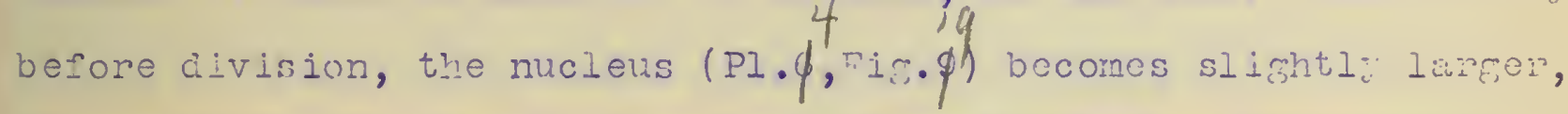
(seven to eitht micre in diameter) then in the resting stise (five to six micra), the laryoplusm becomes more coarsel: puticuIated, or alveolated, and the crromatin elements stain in shurper contrast to the karyoplasm. The various phases of mitosis (Pl. 7 , prof

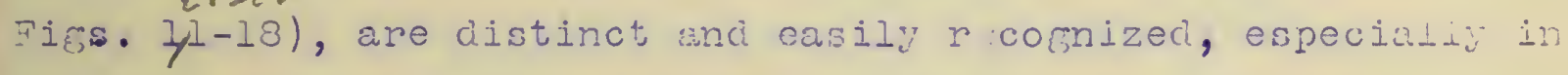
material stained with hacmatoxylin anc orange G; yet, the chrowatir: bodies are small, and cromd together in such a war as to malre it almost impossiola to determine the exact number of chromosomes. In sorne instances, hotever, $(\mathrm{Pl} . \%$, Tig. 1,5$)$ the number of chromosomes appeared to be sixteen, arranged in eight pairs. The plane of division is trunsverse to trie axis of the storich. Insects lidlec? inst after the aivision of the epithelial wall into two lavers (PI. $\$, F i s .20)$, invariably show mitosis in full progress. In some instunces, a count of ull the nuclei rihich appered in a tangential section of the outer part of the wail shoved fully thirty per cent. of the nuclei to be involved in one or another stame of mitosis. Immeciatcly after division the daukhter nuclei (mig. 1 , dau. n.t, are smaller (three to nive micra in diemoter), and stain more intensely than do the nucloi in the restins, stasco. 



$$
\text { Stage }+\left(P \perp \cdot 7^{6},-i g \cdot \$ p\right)
$$

Folioving the soparation of the epitheliur into tro layers, the oliter lawer (ect.) eraciually decreases in thickness und returns to the rosting condition. The inner purt (ent.) consisting of Inosely organized cytoplasm, and containing nuclei (n-), concretions (conf) anci parasites (par/), becomes enclosed in a rarabrane precisely similar in structure and origin to that wich encloses rood in tre stomach; it is, then, another peritrophic mermbrane. The whole mass, which since sture IT, has occupied the entire digestive cav-

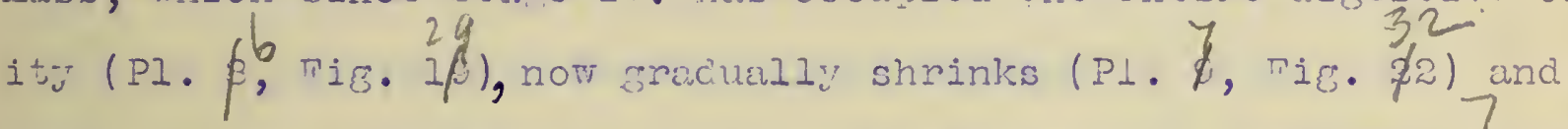
the cytoplasm undergoes marled changes in appeurance (PI. $\phi, 0 i g .01)$. The ilveoli (alv,) and vacuales Vtald coalesce and finally broak down, leaving cnly fragments of cytoplasm which have lost aIl alveolation and become meroly granular, and which for the most part, eventucliy cisappear. The nuclei offer, apparently, more resistunce to the process of deceneration than cioes the cytoplisn, retuinine, their icientit; aftcr the alveolation of the cytoplasin is lost.

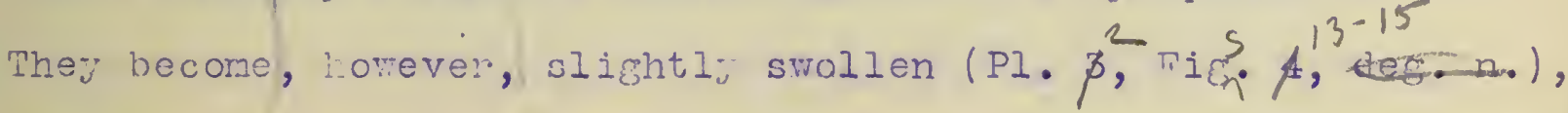
and lose the nuclear merabrane. The chromatin boclies (chr. Fig. of each nucleus remain for w time in their relative positions, bus finaliy becorne separated from one wnotror and scattered abrut, on eise agreguted in irregular masses. The concretions (PI. $\$, 1$ if. $\$ 0,30$ con.t alone, of all the elenonts which trere formerly a part of the epitheliurn, are una fected by the process of degeneration. Parasites, if prosent, also remain unaltered and are cast out of the alimentary canal, but these, of course, have neven been in a true sense, a part of the epitheliun. The residue, which is esecteci from the alimentary canal at once ufter ecdysis, consists almost 

entirely of the concretions alreacly rofersed to, with the fracrents of chromatin matter, all massed solidiy togetier.

\section{REGEIERATIOH.}

The process of degenenution rhich I heve cescribec is quite distinct from the $r$ generation of the opithelium of the mid-intestine, which latter process has beer foli ü described b" Trenzel fon Coleoptera, Distera, Lepidoptera and Hymenoptera. IIo saus ( $185, \mathrm{p}$. 293): "Bescgnet man auch in den Schnitt_präparaten, besonders in denen der Ijmenopteren und Schmetterlingslarven, einer AnzahI kleinerer basal im Epithel sitzender oder allmählich in die Höhe mickender zellen, aie man sofort als Jugendfomen ansehen wizl. "oher diese Zelien kommen und wie sie entstehen, soll hicn nun veiter untersucht wercien.....-Es wird sich zeigen, dass ran folger den Sitz aufstellon Kann: Die eigentlichen Epithel_zellen im Mitteldam der Insekten, Gleichgültib ob sie dem Darmschlauch selbst oder auch dessen Ausstỉlpungen angehören, sleichg"iltib ferner ob sie dem Typ's der langestreckten Cylinderizellen oder derin ${ }^{m}$ indichen Schleimazedlem zuzuadrlon sind, pflurzen sich auf der vomo, don airelton (amitotischen) Kemtheilun (Ioloschisis)tort, "̈̈rnche? cis spezifischon Drüsenzelien dor Kropt n sich uf der "rere cior incilrekter (mitotiachen) Kerntheilung (Karolyse) vomenron." Faussel ( $187,0.697$ ) finds the regenerative process in Eremobia and Aeschra Larvae to be similar to that described by Trenzel, in $; 0$ far os he (Faussel:) vas able to observe. Tumning to Mhrsanura, to which Collembola are most nearly ullied, we find Oudeman's reference to the process in liuchilis, as follows ('87,p. 192): "Alle meine Beobachtungen sprechen für eine Régeneration des Epithels in 

den tiefen atelien: (l) sind die zellen ciort am kleinsten und cehen gleichmässig in die grösseren über; (2) finden (indirekte ) Jerntheilungen in den am tiefsten liegenden Zellen Statt; (3) ist die Quantitä der ausceschicdenen secrettropfen grösser, je veiter die Zellen von den tiefen stellen entfernt sind und (4) lassen die Rancizellen der Polygonen leichter los und zerreissen auch leichter als die Zellen in der Tiefe."

In collembola, as compared wh other insects, the conditions are much simpler; for the regeneration of the epithelium cioss not proceed from local ageregations of cells, but takes plince throurholit the epitheliul layer, by means of cell-division, as I have obsemva. Furthermore, the nuclear division is mitotic in Collerboli, insteace of amitotic as it is saic to be in other insects.

\section{SECRETION.}

The epithelium of the middle region of the stomach is marled by the frequent occurence of cells (PI. $\$$, ris. $\$$ \$, sec.c. ) the contents of which are consicuously clear, on account of the excessive amount of vacuolar fluid and the reduced amount of inter-vacuolar substance. Scattering cells of this type are fo' nd on oll sides of the lumen and as far down the dimentary tract as the posterior part of the third abciominal segment, but they are most numerous on the ventral side, and in the region of the first abdominal segrent. In specimens which had not eaten for some time previous to being killed, these cells rere so distended with fluid as to project for a distance of tro on three nicra into the stomach cavity, and the vacuolar contents were dense enoufh to crowd the nucleus to one side or to the base of the coll. Those clear colls, which I have 

observed also in the stomichs of other insects (as the linvi cf Bombyx moril are speciclized for the purpose of secr tine a copious fluid, which accumulates in the cell when no food is tulien into tre stomech, but othorvise passes throuch the intind to mix with the food.

In insects winch had fasted for five or six days, large vacuoles occurred around the nucleus (PI. 10, Fig. 2年) and often a

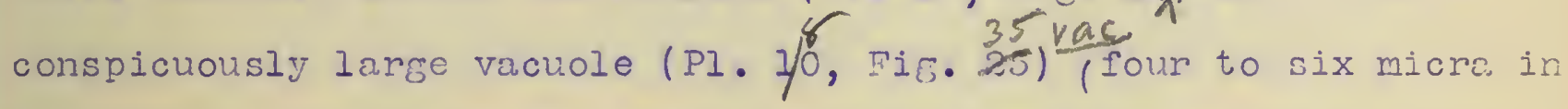
dianeter) occurred in each cell, neir the intira. These vecuoles also, I infer, contain accumulased dicostive secretions. In a few instances, after the insects had fasted, the epithelial wall was

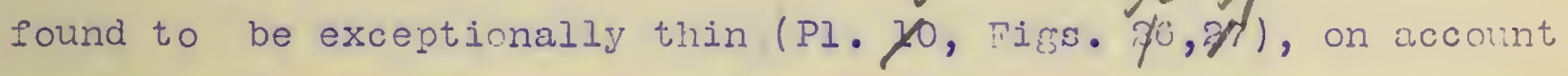
of a reciuction of cytoplasmic substance, probably by absorption into the blcod.

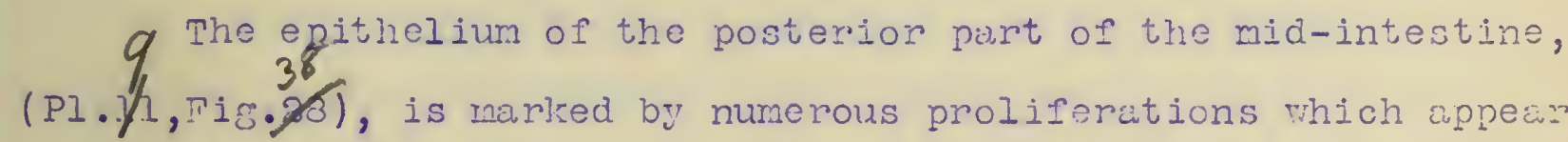
on the ental surface of the cells and project into the lumon. Since these proliferations are found in various stages in the same individual, it is not difficult to trace their oriein uni development. The cclis of this region are long and narrov and are crovded tojether more closely than those of the midile anc' anterior regions of the stomach. A cell of this kind, turgid with digestive fluid, becomes convex on its free surface (Fig. $2 \beta$, sec $\frac{p^{\frac{1}{2} y^{2}}}{y^{2}}$ ). This convexity increases, carrying the intima before it, until a part of the coll projects into the Iuren (sec.p.3.). Next, the connection betreen the projection anc the cell constricts (4) until there results the sepurition of a spherical bociy (f), six to eight micra in diametor, exclisive of intima, made up of ordinamy cytoplasm 

frequenty containing concretions but invariably rithout a maleus. After becoming free in the digestive cavity, the spherical body loses its intind (inf), becomes less definite in outline anc stains loss deeply. The vicuoles and alveoli breal dom, their contents escapins to mix rith the mains for a short time faintly granular, but soon discippeirs. It appears that this process also is one whereby digestive fluids which have been elaborated by the cell, are given off to act on the food.

Gehuchten has described the process of secretion in the larva of ptychoptera. According to his observationslas quoted by Packark, pp. 320-329), when an epithelial cell is about, to empty its secretion into the alimentary canal, the coll becomes distencied and a part of the cytoplasmic body projects into the disestive cavity. A glandular call of the chylific storach, when at rest, is furnished vith a striated "platform" on the difestive surface, the platfom being provided with filaments. But when active, the cells prisent a vory different appearance, since in many of them the platfom has disappeared, and is replaced by a simple membrane. During the process of secretion, a finely ejranular mass, continuous with she cutoplasu, swelis, raising the limiting membrune over the entire breadih of the cell, ark causinf it to project into the lumen. A pear-shaped vesicle is thus formed, which evontuall:" is constricted off from the cell and set free in the lumen of the storach. These vesicles, both before and after separation from the cell, are clear and transparent in the living insect, but, more cranular in the tissue fixed for soctioning. Gehuchten then describes.a modification of the process rihich occurs when 

secretion is mosic active. Ihe limiting mombine nav then be raisea in several places at once on a single cell, and several vesicles may form instead of one. After becoming cietaclied from the cell, these vesicies mpture unc their contents mix witl the fooc. Needham ('98, pp. 103-113) has described the decumulation and discharge of the disestive secretion in dragonfly nymphs, in which the digestive epithelium is of the sane type as in Orthoptera. Interspersed bettieen the cylinaric cells are Groups, or "nidi" of small, roundish cells, close to the basement merbrane, and havina no communication with the cigestive cavity. The secreting process consists in the accumulation of granular material in tive calls midway between the nidi. These cells then rise in elevations with tursid sumnits from which the striated border has disappeared, and a globule is discharcod as if crowded out by compressin from ¿ajacont celis. Fuch çlobule discharged represents the larer part of a coll, includine, generally, the nucleus. Needham arrees with most other recent investigators, in c nsidering the nici to be centers of regeneration in which new cells arise (p. 113)"by division, Grow, crowd their way to the surfacc, acquire a striated border, become functional, secrete, discharge, digest anc die, giving place to others which in turn mun the same course."

Certain differences vill be seen at once between the processes of secretion as described by Gehuchten and Necdham, anc the process in Collembola, since in the latter the proliferation does not burst through the intima, but is still covered b": the striated mombrane when constrictec ofr. Moreover, in collembola the discharece portion does not represent the greaton part of the cell, nor does it ever include the nucleus, as in the dragonfly nimph. 



\section{CORCLUSION.}

That is the meaning of the periodical degeneration of half the epitheilial wall of the mid-intestine? Sommer has succestad one use of the cast-off epithelium. He siys, (p. 715): "Ob die abgestossenen Zellen dem Thiere während der Häutung, wo dasselbe keine stoffe von aussen aufnimmt, zur Tahrung dienen, lässt sich mit Bestimmtheit nicht behaupten, ist aber nicht unvahrscheinlich." This vier is supported by the decrease in quantity of the cast-off material before it is finally ejected; for the evident cxplanution of this ciecrease is thut the nutritive elements are cigested and resorbed. This is merely incidentil to a larger process, hovever, which must be accounted for: While the insect is groring, the Erowth of the stomach is effected by a constint increase in the number of its celis, through mitotic division. A simple explanation, then, would be that this phenorenon is merely an incidental result of the continuance of the ordinary process of cell-division after the stomach has reached its maximum size; when, thenefore, the surplus cells with their nuclei must be disposed of. It is evident, however, that the phenomenon is something more than an abnomal prolongation of ordinary cell-multiplication, from the fact that it is not confined to full crom incivicusls, but occurs throughout the life of the insect.

A second possibility that surgests itself is that the phenomenon is a secretory process. It is alrewery knom that amon insects of several diverse orders (see p.22) some of the cells of the stomach cast off each a portin of its cytoplasm in the form of a roundec vesicle, the cont ants of vilich mix with the food in the lunen of the stomach. Huve ve here esscntially the sume thing, 

except that it involves tle entire spitheliul rall, instous of being local, and involves nuclei us well as cytoplesm? The answe: is,--no; for at the time of the castin-off of the epithelium until its remains are discharged from the rectum, there is usually no food whatever in the alimentary cunal, anu at most, only the slightest traces of fook.

The most reasonable interpretation at rhich ${ }^{\text {Wh }}$ have $b$ : en able to arrive is the following,-- an induction from the facts observed. Soon after a molxlt, when feedine is raslined, or even before food is ecten, peculiar concretions ( see p.J ) appear in the cells or the stomach. These concretions increase in number continually. They are scattered throughout the cell until it is nearly time for t?:e moult; then they accumate in the ental half of the cell, which is soon cut off frora the rest of the ccll, anc cast, with its contents, into the lumer of the stomach, where the concretions remain intact until they are ejected from the alimentary canal. These concretions form in the cell as products of cell-metabolism; they increase with the are of the cell; they are insoluble in the blood of the insect, and are highly resistant to ordinary chemical reacents, (seepp.9-10); they eventully load the cell, become segregated at the inner end of the cell and are then cast off. Therefore I regard thern as excretory products. Being insoluble, tricy ire romoved bodily, and this romoval is accomplished by cell-division. Though the removal involves an initial sacrifice of half the cytoplasm, and half the number of daughter nuclei, the fluid contents of both these wre resorbed by the remaining epithelium, before the concretions, chromatin matter and fragments of disintegrated reticular substance are expelled from the body. 

Concretions of preoisely the same kind, though lamer, wre deposited in the rat-body of voliembola, where they increase in number with the afe of the insect and where they remain until the insect dies.

If these concretions are indeed uric acid or one of its derivutives, as villem maintains, that is additional and most important evidence in favor of my excretory theory.

This conclision-that the stomach in collembola has an excretory function, - is of course unique for insects. But Collembola themselves are unique among insccts (excepting possiby Jaryx) in having no ralpigian tubes for tir extracti $n$ of vaste prodicts from the blood, and excretion is one of the vital necessities of any cell.

\section{SUMMARY.}

In collembola, a deceneration of the inner half of the epithelial wall of the mid-intestine occurs in connection with each ecdysis. The cells of the rnid-intestine become confluent and important changos of alveolation ensue; nearly half the nuclei miErate toward the intima, while the rest of the nuclei remain near the basement membrane; a wall now forms between the two sits of nuclei, iividine, the epitheliur into two concontric layers. The inner of these two layers cierenerates; the crioplasmic reticulum disintegrates; the nucleur merubrones disappear and the chroukin cranules become scatterod, but romain intact; much of the fluid substance is resorbed into the remaining layer of cells. The disorcanized epithelium, surrounded br a peritrophic mernbrane, is expelled throuch the rectum shortly after the extemal moult. 

The process is an cxcretory onc. By this means, the nupicily accumulating concretions of socic urate wie removed fron the cells of the mid-intostine, as are also, but incidentally, unicellular parasites (Gregarinidae).

The muclei lost by degeneration are replaced by the mitotic division of the remaining nuclei,--this occurring before the inner portion of the epithelium is cast off.

The peritrophic :embrane, which colvoys envelops a food-mess, is fomed by the wplitting of the intima, and is therefore a secretion from the epithelium of the mid-intestine. The wal that civides the originaldy single layer of cells into tro lwjors, splits into two membranes, one of wich surrounds the degenerating epithelium as a peritrophic membrane, while the othor forms the ner intima of the mid-intestine.

The fomation of new cells takes pluce throikhout the epithelium, by mitosis; this reneration does not occur from local centers, or "crypts", as it does in other insccts; furthermore, no amitosic divisions are found at any time.

Secretion is performed (I) by the ceneral epithelium of the mid-intestine; ( 2 ) by special clear cells in the middle region of the stomach; (3) by specialized cells in the posterior region; these last sive off proliferations into the lumen, which become constrictec off, us free, rounded, cytoplasmic vesicles, which breik dom in the alinentary canal und mingle their contents with the food. This novel rôle of the mid-intestine as an orcun of excrotion is correlated with the absence of Malpimian tubes in Collembola. 

Biulbiani, E. C.

'so. Fitucles anatomiquos et histologignes sur le tube i estif des Cryptops. Arch.Zool., cxp., T. 8, pn. 1-32, G Pls.

Cuénot, I.

95. Fitud s phrsiolocigues sur les orthoptènes. Arch. Biol., T. 14, pp. 203-3il, PIs. XII, XIII.

Tabre, J. L.

'50. Étude sur l'instinct et les nétumo rphoses des sphegions. Ann. sc. nat. Zool., Sér. 1, T. 0., pp. 137-180.

Fausser, V.

'87. Beiträge zur llistologie des Iarmkinis a ar Insekt Zeitschr. wiss. Zoöl., Bd. 45, pp. 601-712, Taf. 36.

Fermald, H. I.

90. The Relationships of Arthropods. Studies Biol. Lib. Johns Hopk. Univ., Vol. 4, pp. 431-513, PIs.XLVIII-L.

Tolsom, J. W.

'co. The Matomy and Physiolong of the liouth-parts of the Collembolan, Orchesella cincta L. Bull. ins. Comp. Zoöl., Tol. 35, ITo. 2, Pp. 7-30, 4 Pls.

Trenzel, I.

'85. Einiges übor den Vitteldarm der Insekten sowie über Epithelregeneration. Archiv micr. Anat., Bdr26, pp. 220-306, TaI. JII-IX. 

Gehuchten, A. Tius.

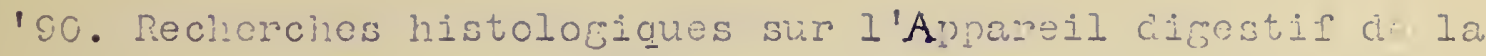
Lurve de la Ptychoptera contaminatia. I Part. F́tude du revêtment épithéliul et rechorches sur liu ścrobtion. La cellule, I. 6, pp. 185-289, Pls. I-VI.

Grassi, B.

'30. I progenitori degli Insetsi e dei l'iriapodi. L'aprz e la Campodea. Memoria II. Atti Accad. Cioen. Sei. Nat. Catania, Sor. 3, T. 19, pp. 1-67, Tav. I-T.

lietschnikoff,

'83. Untersuchungen üher die intrazelluläre verdaming bei Wirbeliosen Tieren. Arb. Zö̈l. Instit. Vürzburg, Ba.5, pp. $141-1<8,2$ Taf.

Needham, J. G.

108. The Digestive Epithelium of Dragonffly nymphs. Eöl. Bul1. "ol. I., pp. I03-1I3, Pigs. I-S.

Nicolet, II.

'4l. Recherches pour servir à l'histoire des Podurelies. Extr. ITouv. llém. Soc. Ilelv. Sci. Mat. Neûchatel. Vol. 6, 84pp., $9 \mathrm{Pl}$.

Oudernans, J.T.

'87. Beiträge zur renntniss den Thysanura und Collembola. pp. 147-226, Tai. I.-III. Amsterclar. 

Platean, F.

173. Recherches our los phéroniènes de la cipestion chez les insectes. Irém. Acad. poy. Bezgique, Sér. 2, T. 4I, 124 pp., 3 Pls.

Packard, A. S.

'98. A Text-book of Fntomology. The inacmillan Co., IT. I.

Schnoidor, $\Lambda$.

'87. Über den Darm der Arthropoden, besonders der Insecten. Zoöl. Anzeig., Jahrs. 10, pp. 139-140.

Somner, A.

155. Über Mucrotona plumbea. Beitrüge zur Anatomie der Poduriden. Zeitschr. wiss. Zoöl., Bd. 4l, pp. 683-718, Taf. XXXIV-XXXY.

Tuliberg, $\mathrm{T}$.

172. Sveriges Podurider. Koncl. Svensk. Arad. Tiancilincar, Stockholm. Ny Töljd. Bd. 10, ITo. 10,70pp. İ Pls.

Vi... I em, V.

'OO Recherches sur les Collemboles et les Thysanoures. I'em. cour. L'Acad. roy. Belgique, T. 58, I44 pp., 17 PIS. 



\section{\%. explatiatiog op plates.}

All figures are of momocems nicer Rourl. Outlines of cravings vere macie with an Abbé camera lucida, and unless otherwise specified, were manified 750 times and drum three times this size. Detail is represented as seen with a l/lo homogeneous oilimmersion objective.

- EIST OF ABBREVIATIOIS.

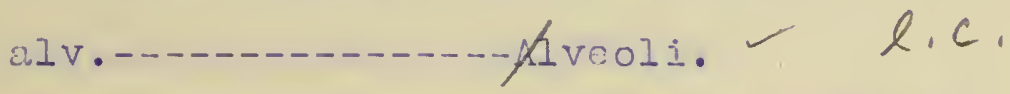

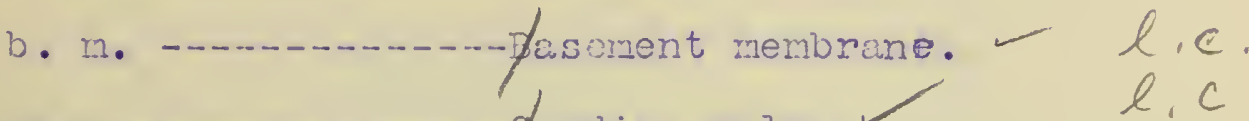

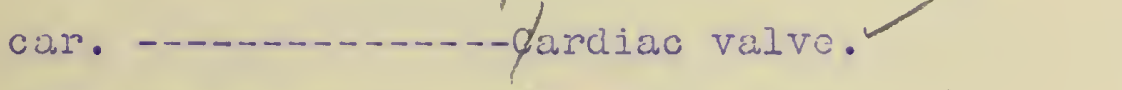

chr. - - - - Chromatin body. $\checkmark$

c. r. -..........--dircular muscle. -

con. -................. Concretion.

dau. n. - ......... paughter nucleus.

deg. cit. -........- tecenerating citoplawn. -

deg. n. -.......-Deçenerating nuclous.

ect. - - - - - - - - - Ectal civision of crtoplasm.

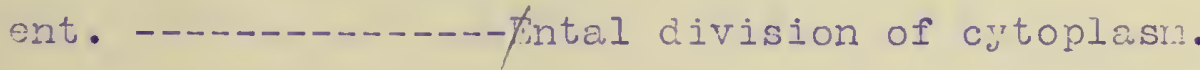

food. - - . - .

f. int. -...-...-pore-intestine.

1. int. .............tind-intestine.

in. -...... - ...- Intima.

e. Humen. Iat.

fateral wall.

l. ra. -..........-tongitidinal miscle.

mig. n. - .

m. int. -.........

n. .................... 

n. 1. -huclear aenbrane.

$n+$. ifucleolus.

pir.

Paresite.

per. m.

Peritrophic membrane.

p1.

Plasra.

pyl.

ṕyloric valve.

$\mathrm{s} \in \mathrm{c} \cdot \mathrm{c}$.

gecretory cell.

sec. p.

Secretory prolifonetion.

$\mathrm{Vac}$

- facuoles.

Plate 1.

Iig, 1. Sagittial section of Tomveens niger, $\times 112$.

pente 2

Irg. 2. Epithelium of mid-nitistine at Stange 1 (resting estage); radial section of mirl intestine Iig. 3. Outines of celle of mid nitestina in crose section. $\times 630$.

Irop. 4-11. Iregannies si varims conditions. Irg. 12. Inegaina (par) in epectichale wall of mid-intectine of an insect which had factad for ein dayp; radial section. Irgo. 13-15. Evieintegrationg molein fromd in the abimentary caral.

late 3.

rndial of the mid-intectine,

Irg. 16. - Portion of $a_{1}$ section, cherwang ongin of peritwe hic membirame from 

relate

Jig. 17. Eptesinem of mid-intestimes it Stage 2; radire section

Jg. 18. Dounghter-matein in abtermatising position; ratine section.

Jig. 19. Epithelimam of mide-nlestine at Sage 3; radiale pection.

Plate 5

Jig. 20. Epithelimm of mid-intesting at 8tage 4; radial section.

grop. 21-25. Phases of mitosis in malei of epittelium of mid-intectine. Jig. 21, metaphase; Jigs. 22-25, ansphade.

plate 6

Jigs. 26-28. 79 hases of mintises in malei of efithelinom of mid - intestine Irigs, 26, 27, andehras; Jig, 28 telophase

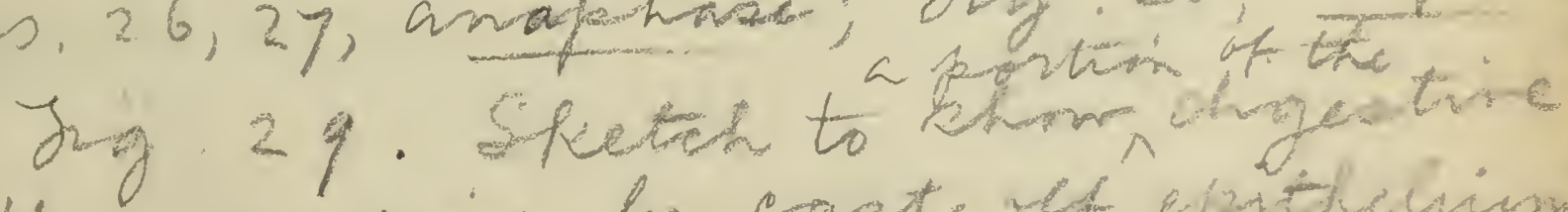

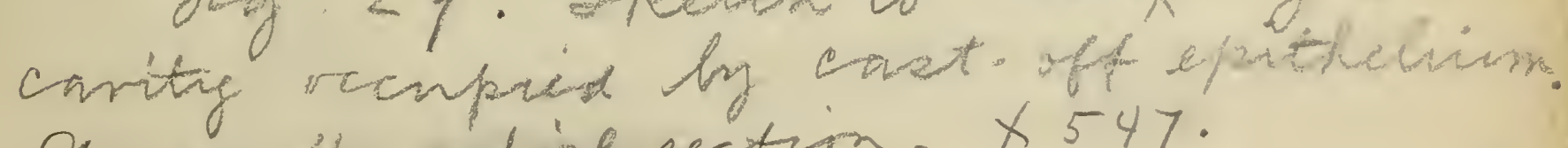
St a ge 4; radial section. $x 547$.

Iig. 30. Epithelinm at Strigm ; rachal section. 
Platé I.

$\checkmark$ ᄀi.. 1. Sagittal section through entire animal. $\mathrm{X} \quad 116$. 
PlateI.

Plate 7

Jig. 31. Degonenating cytoplasm. $\times 547$.

132 . Begenerating cytaplasm en closed in paritrophic membrame. $\times 123$. yig. 33. Secretory celle in midede region of mial-intestive; radine section. Jig. 34. Cell from mid-intistine, after frating; rachial euction.

Plate 8

Irigs. 35-37. Calle from mat iniext nie, after froting; rachine suction.

Peate 9

Yrig. $38,39$. Epithehim of perterin region of mid-intestive, them the derelifprmant of eceretory proliferations; radral sections. 



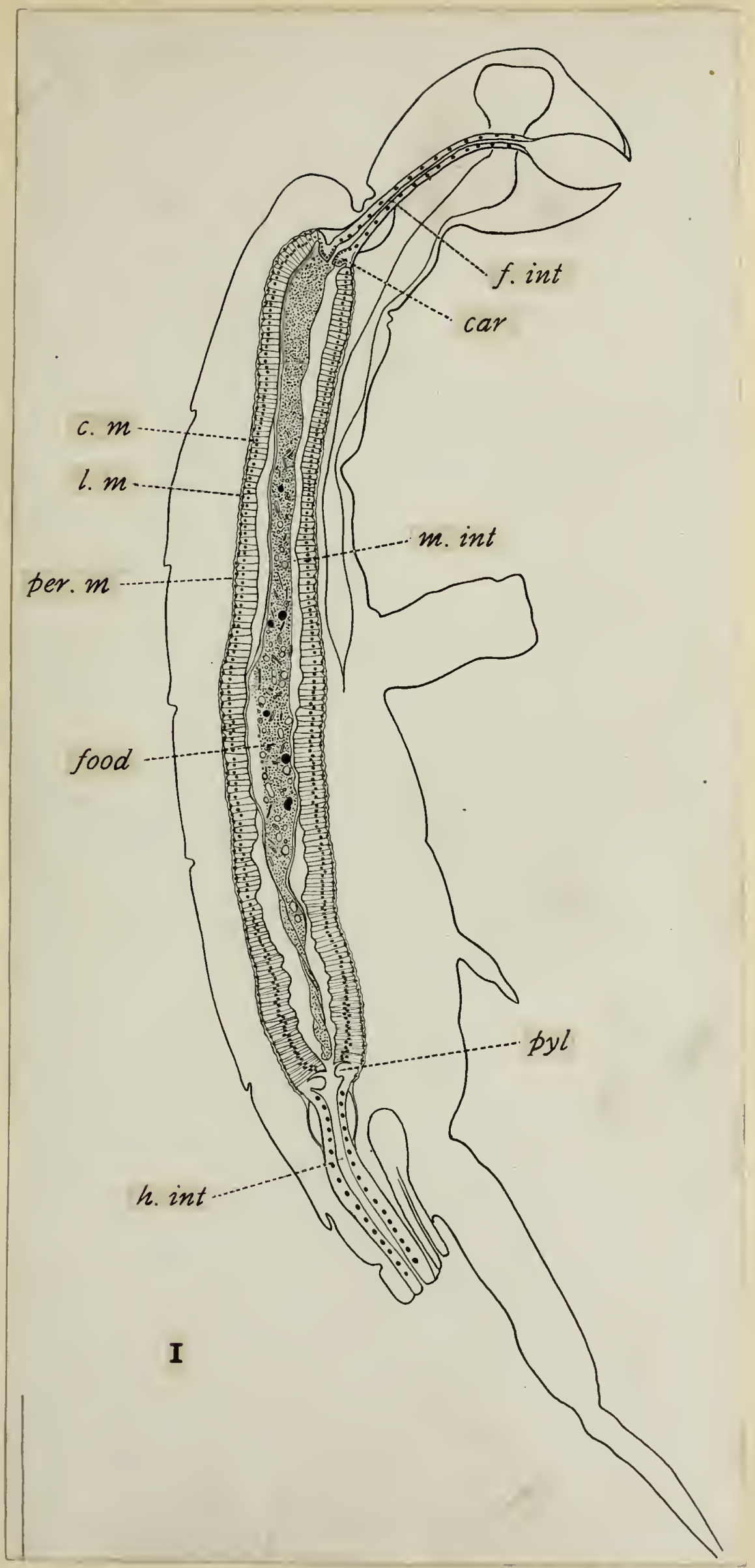


Plate II.

Fis. 2. Epithelium of mid-intestine at Stage I (restincs stage

$\int$ Fic. 3. Outline of cells in cross section. $\times 750$. 
Plate II.
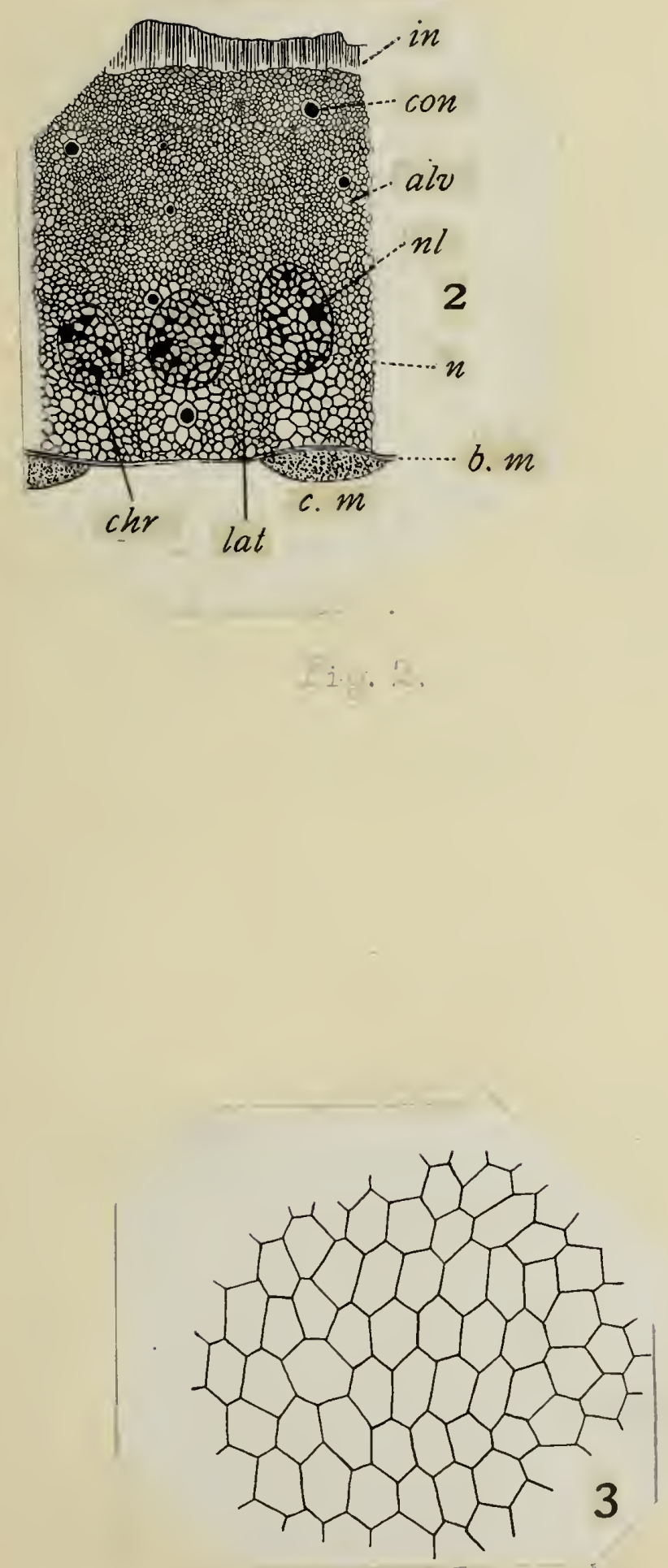



$$
\cdot+2+12+2
$$

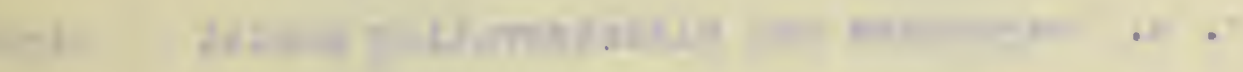

$$
+2.7-2
$$

$$
\text { h. }
$$




\section{Plive III.}

Tig. 4. Gregurines anci disintegruting nuclei of digestive cavity.

Fic. 5. Grofarine in epithelium. (Insect had been deprived of 12 food for six days previous to killing.) 
PlateIII.
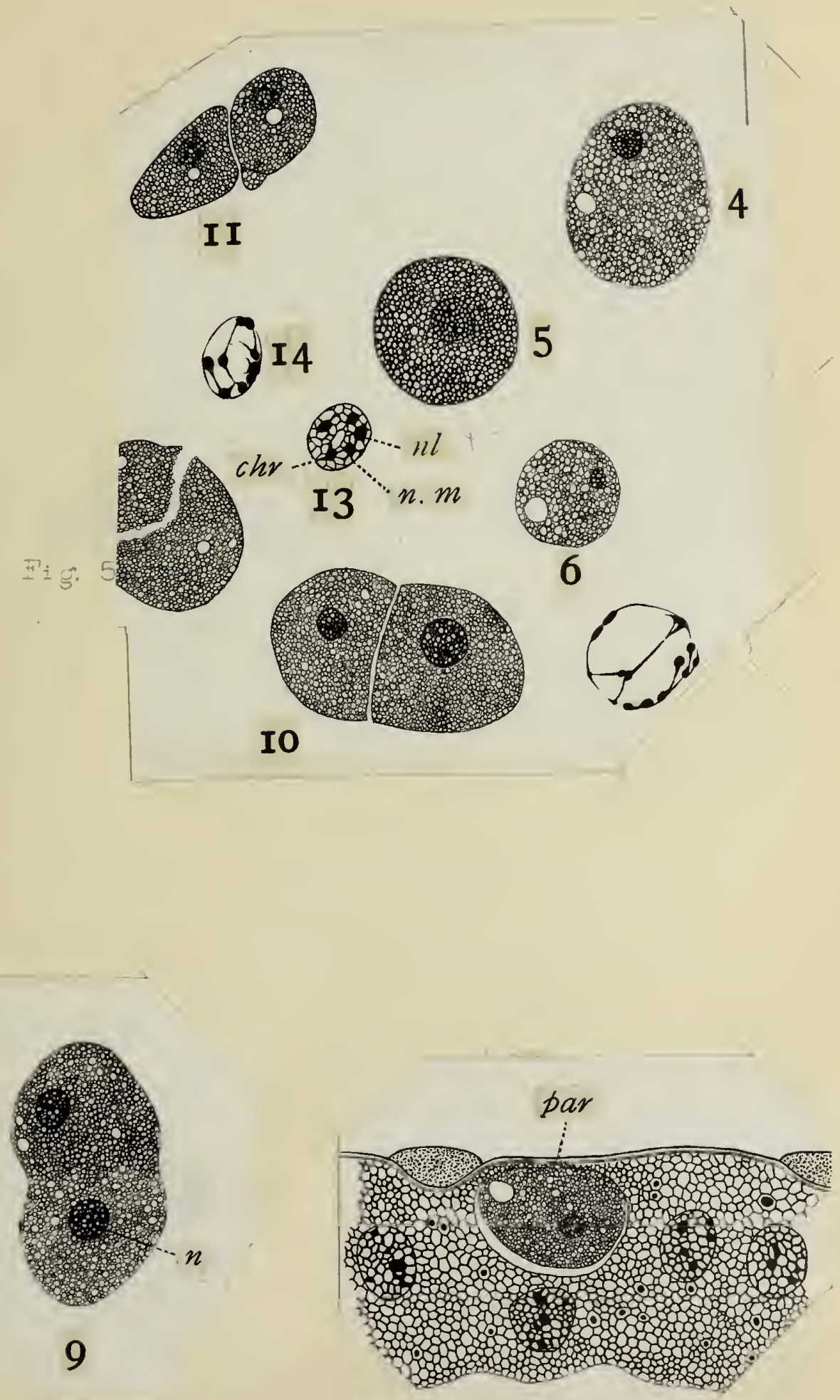
<smiles>C1=CCC=C1</smiles>

- 
-

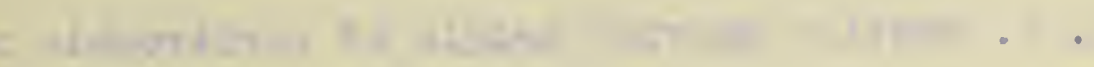

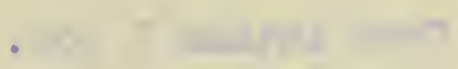




\section{Plate IV.}

lo

Figf. Q. Secticn shoving origin of peritrophic menbrane from intima.x 750 . 


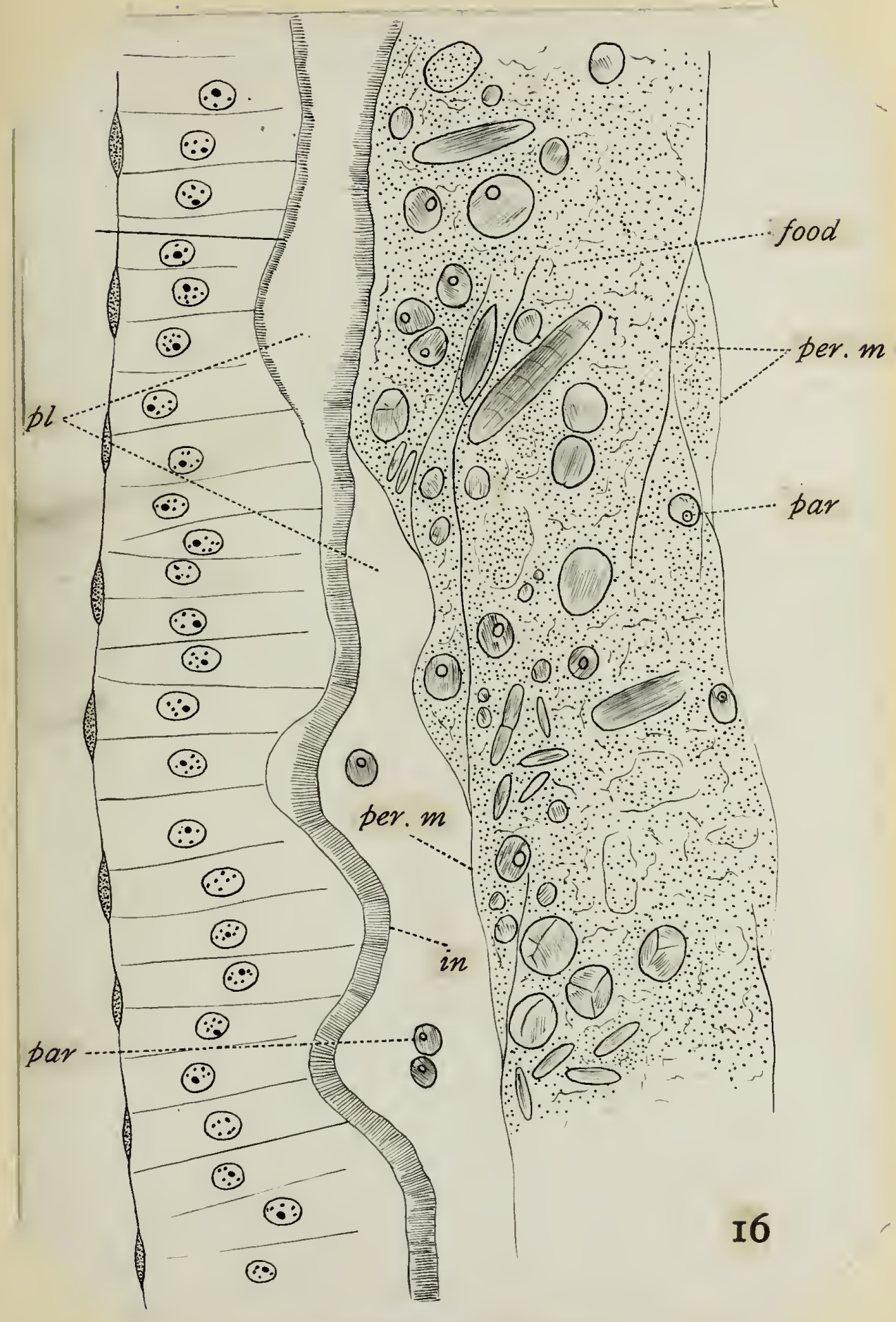





$$
\begin{aligned}
& \text { - } 15+2+1
\end{aligned}
$$

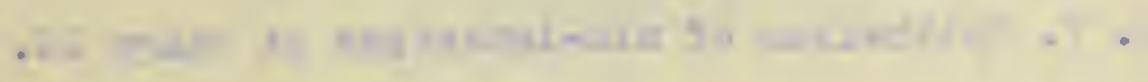

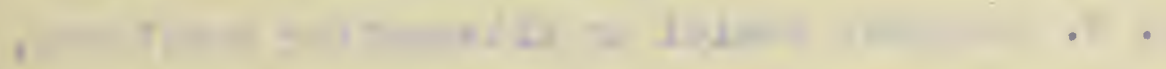

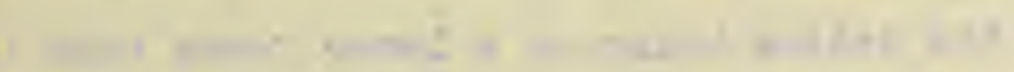

$$
\begin{aligned}
& 1
\end{aligned}
$$


Fic. F. Epithelium of mid-intestine at Stage II.

Fic. 8. Daughter nuclei in altermating positions, those nearer

( the intima being at a lover focus than those nearer the basement membrane. 

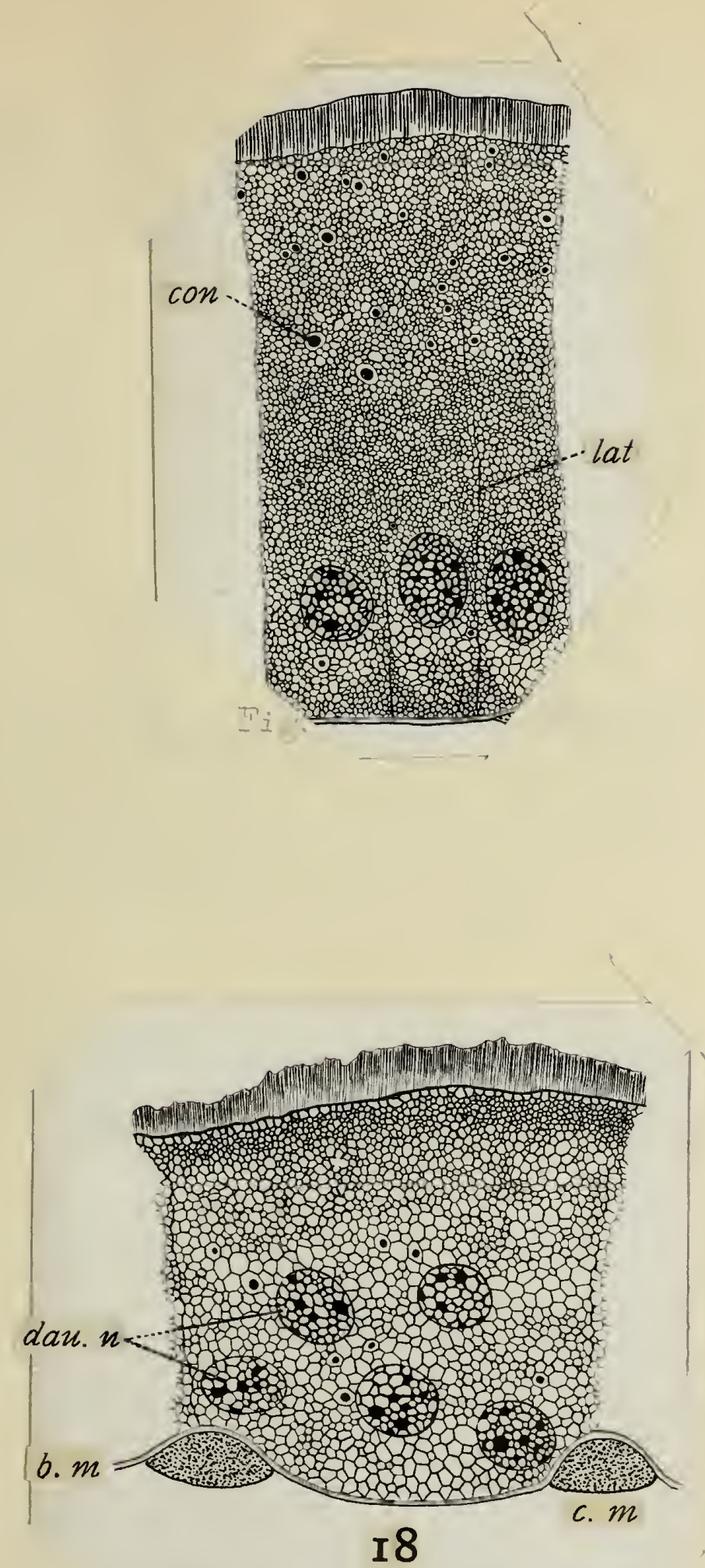



$$
\text { .78 1 15 }
$$

$$
\begin{aligned}
& \text {. II + +5 + }
\end{aligned}
$$

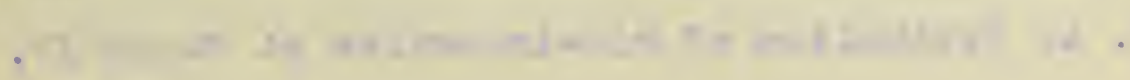


19 Plate VI.

Fis. p. Epithelium of mid-intestine at stage III.

Fic. If Epithelium of mid-intestine at Sture IV. N 

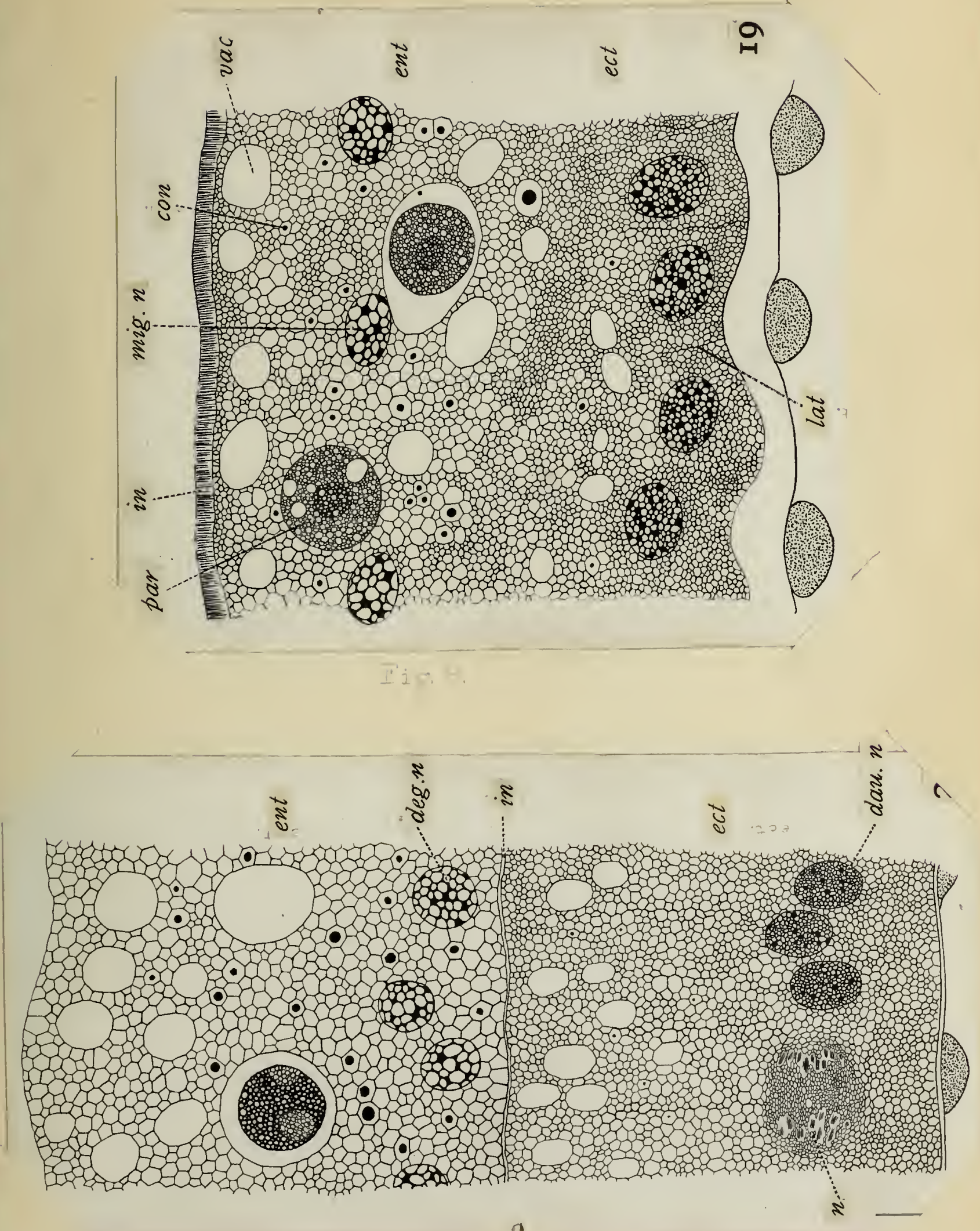


Plate VII.

$\checkmark$ Phases of mitosis in nuclei of epithelium of mid-intestine. Fie. 11. Netcphase.

Fiร. 12. Anaphase.

Pige. 13. "

Nis. 14. "

Fig. 15. "

䰝 $10 . "$

Fig. 17. "

Fic. Il. Telophase.<smiles>C1CC2CCC(C1)C2</smiles> 
PlateVII.
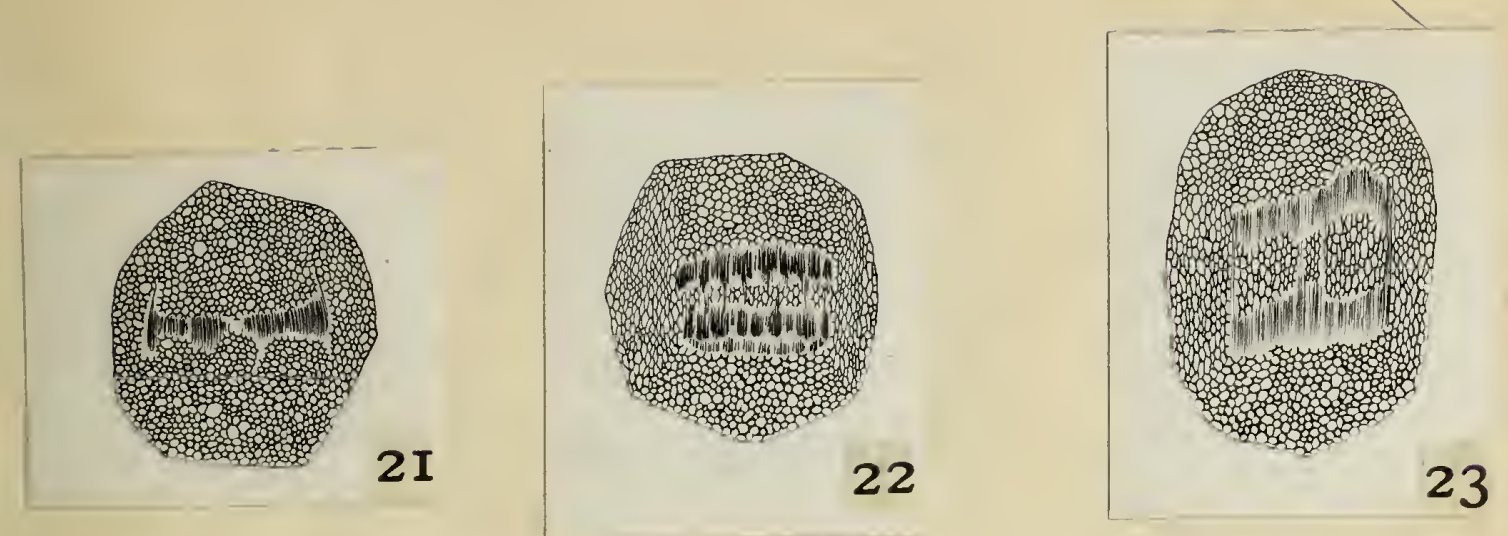

$I i=11$
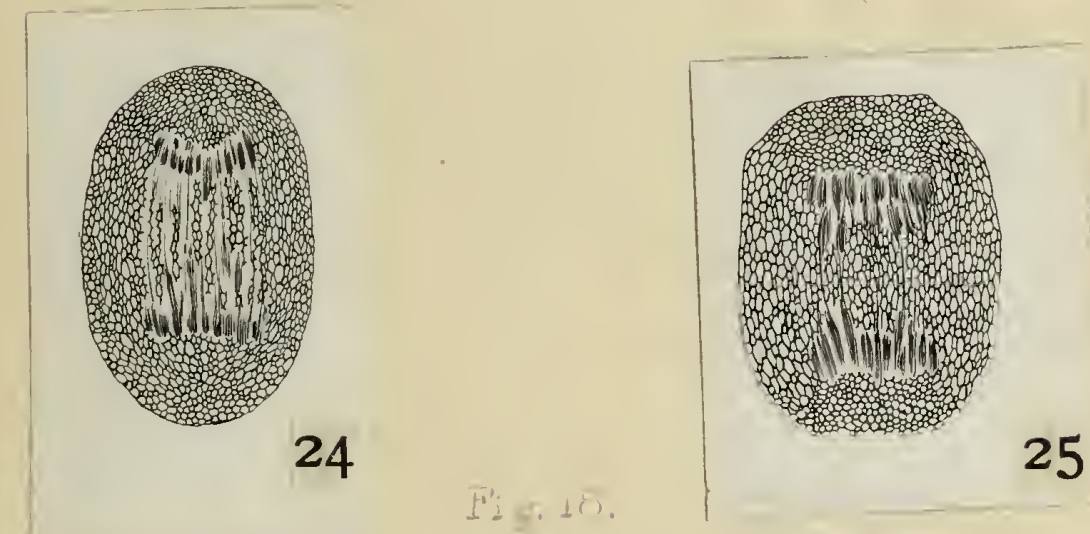

25
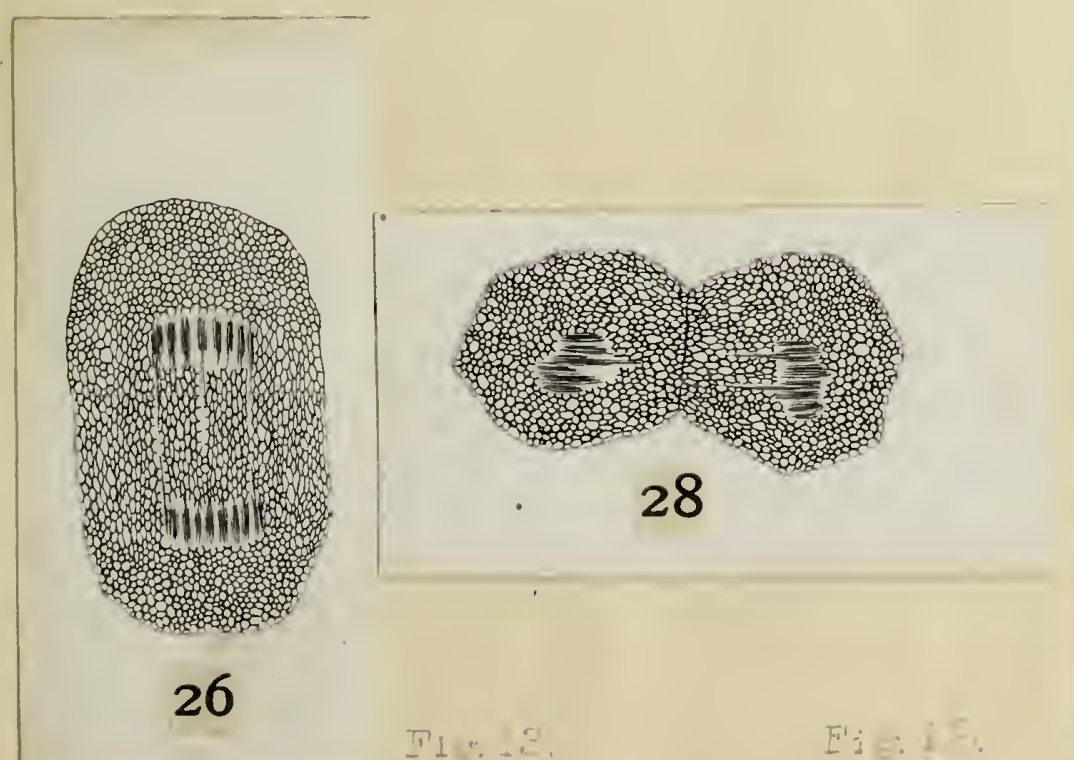

I1: $2^{2}$

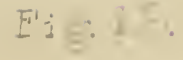

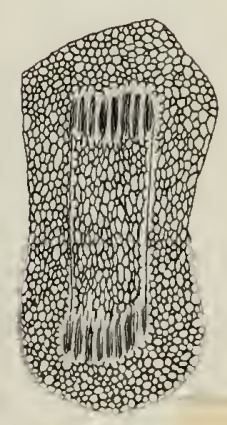

27 


Plate VIII.

Fie. 10. Sketch to show digestive cavity entirely occupied by castoff epithelium, Stine IV. X 050 .

Pic. 26. Epithelium at stane $V$.

n

$-40-$ 
Plate VIII.
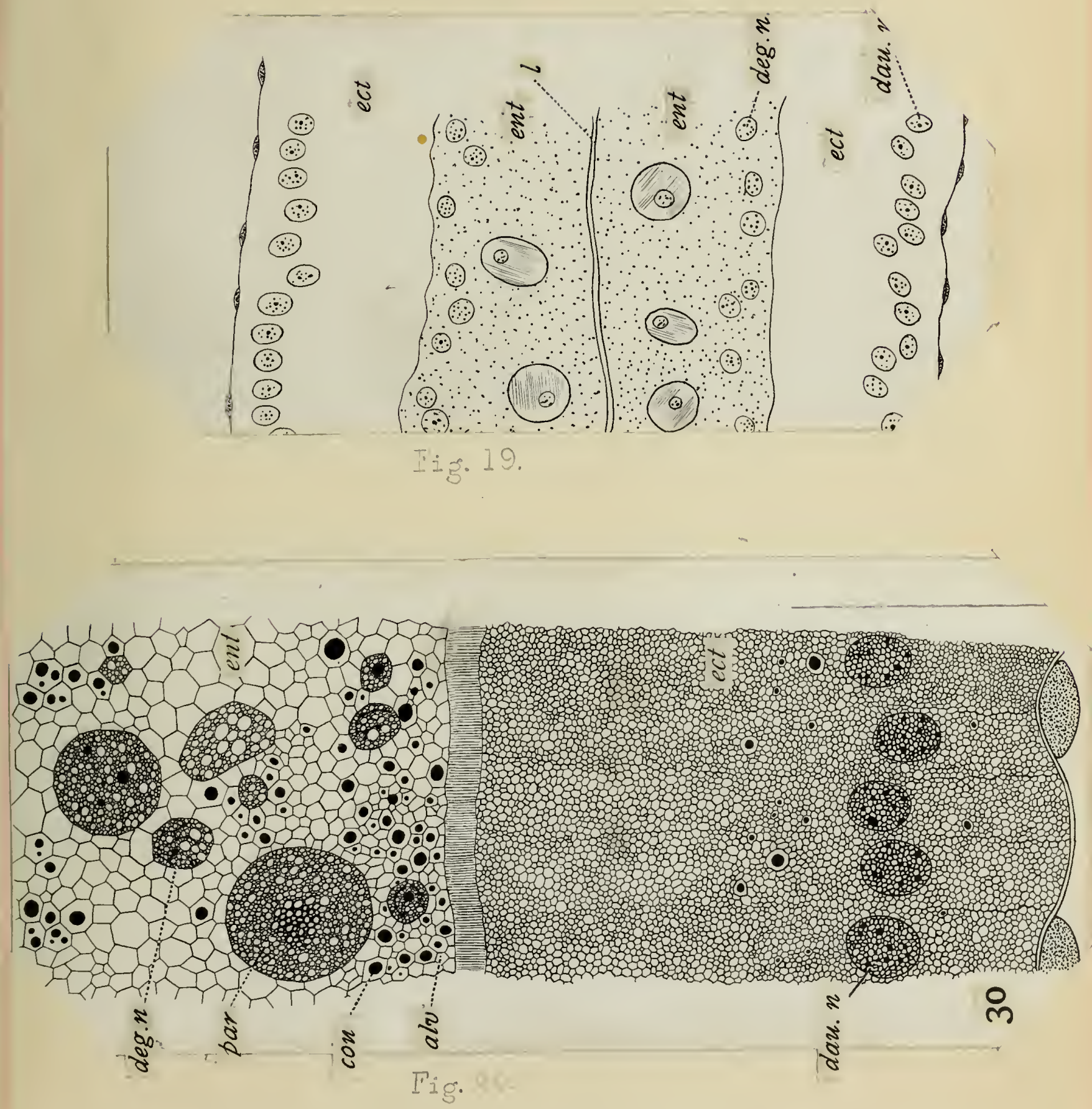



$$
\text { - } 7+7+1
$$

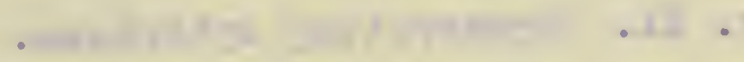

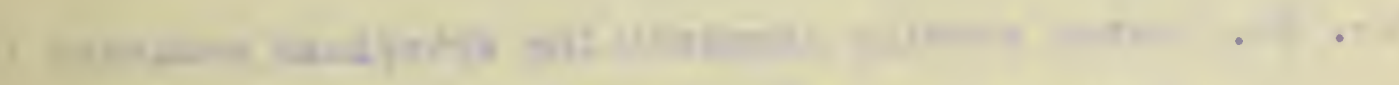

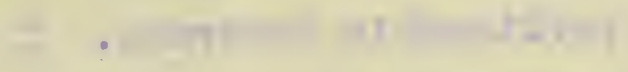

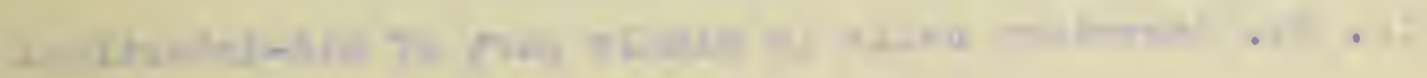


Plate IX.

Fig. 21. Degenerating cytoplasm. X 650 .

Pic. 25. Sketch showing degenerating cytoplasm enclosed in ^ peritrophic membrane. $\times 146$.

Fin. 23. Secretory cells in micile part of mid-intestinal wall.

$$
n^{m}
$$

$-41-$ 
PlateIX.
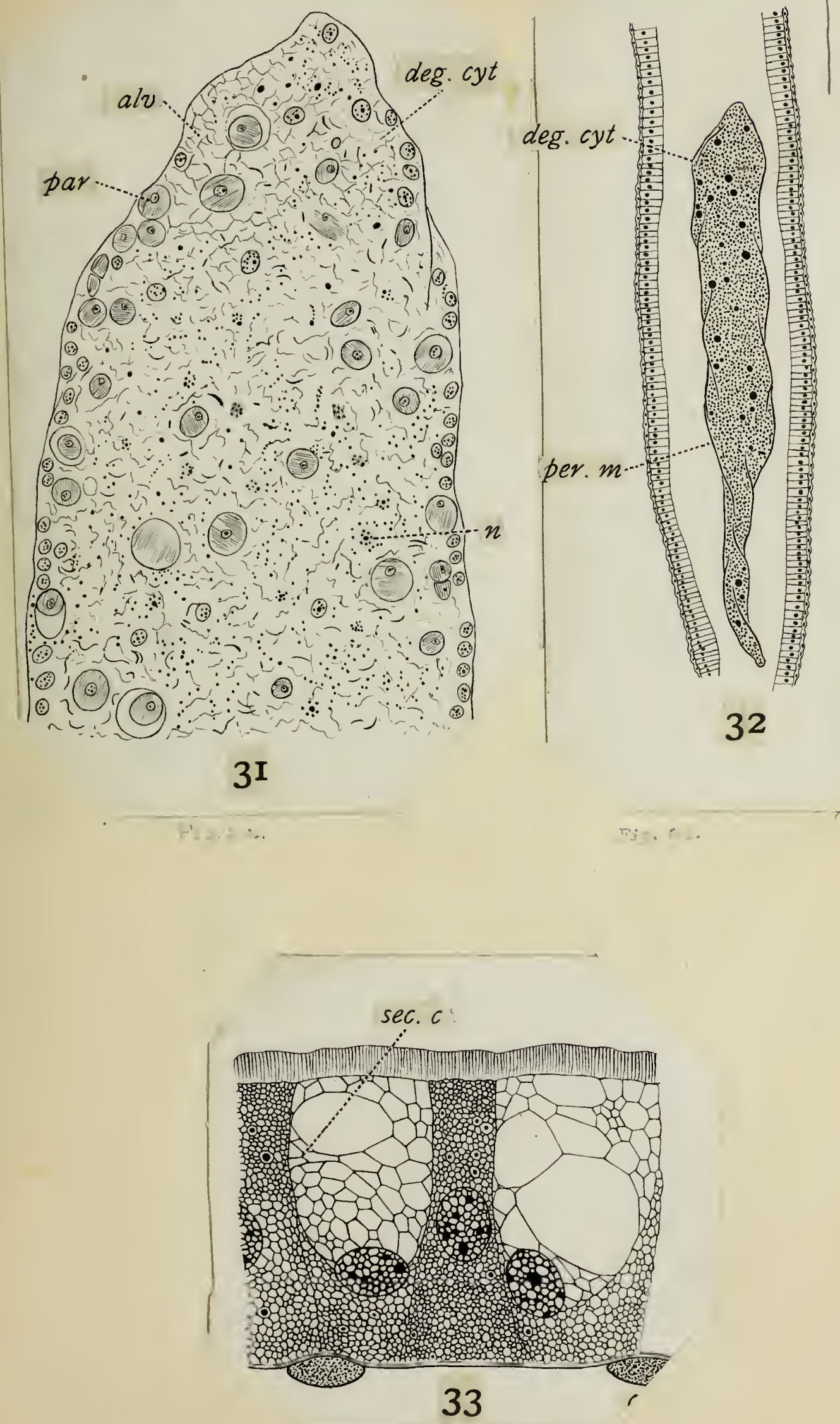

Fig.23. 


Plate $\mathrm{X}$.

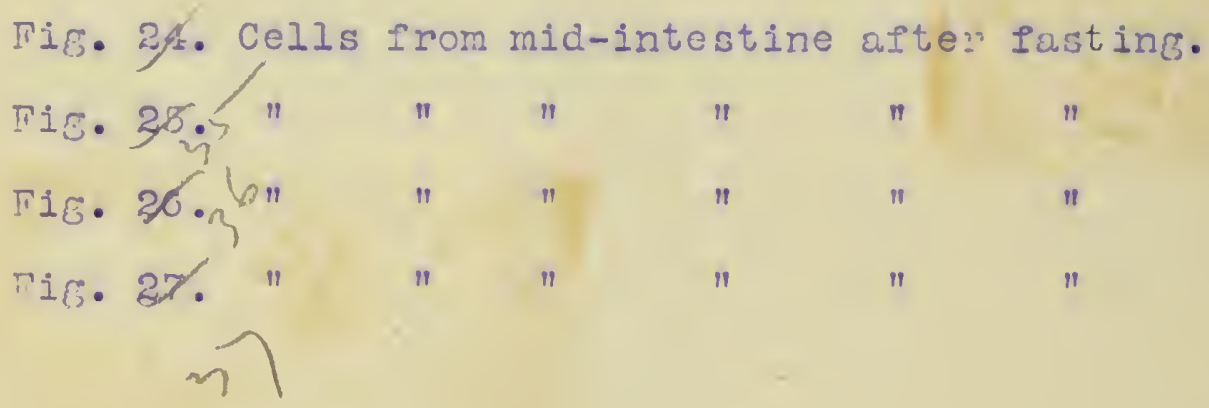

$-42-$ 
PlateX.
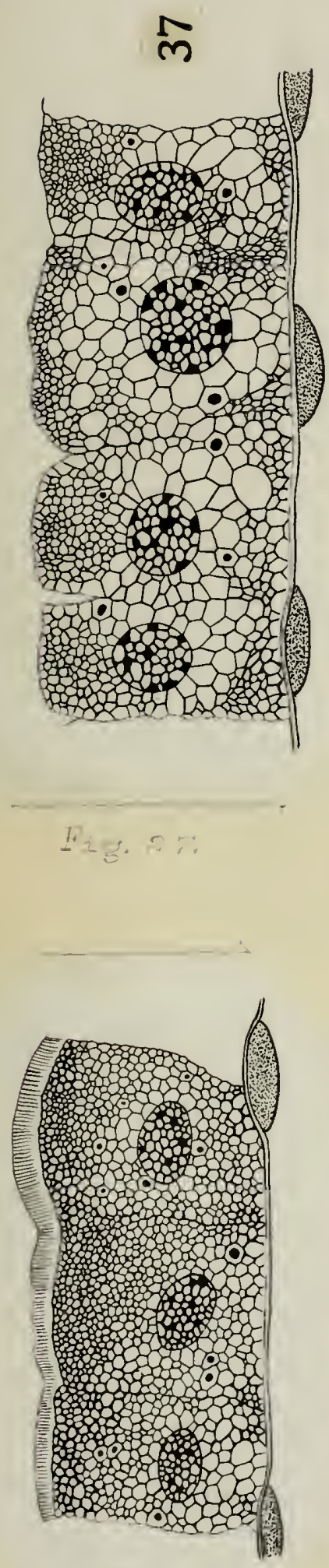
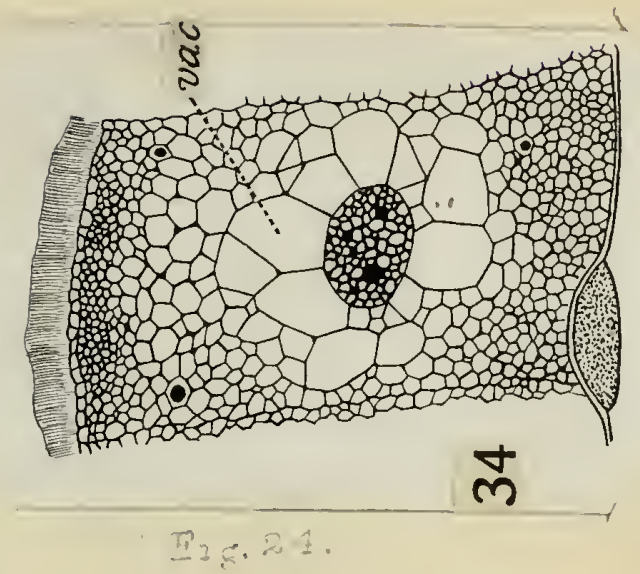

กิ

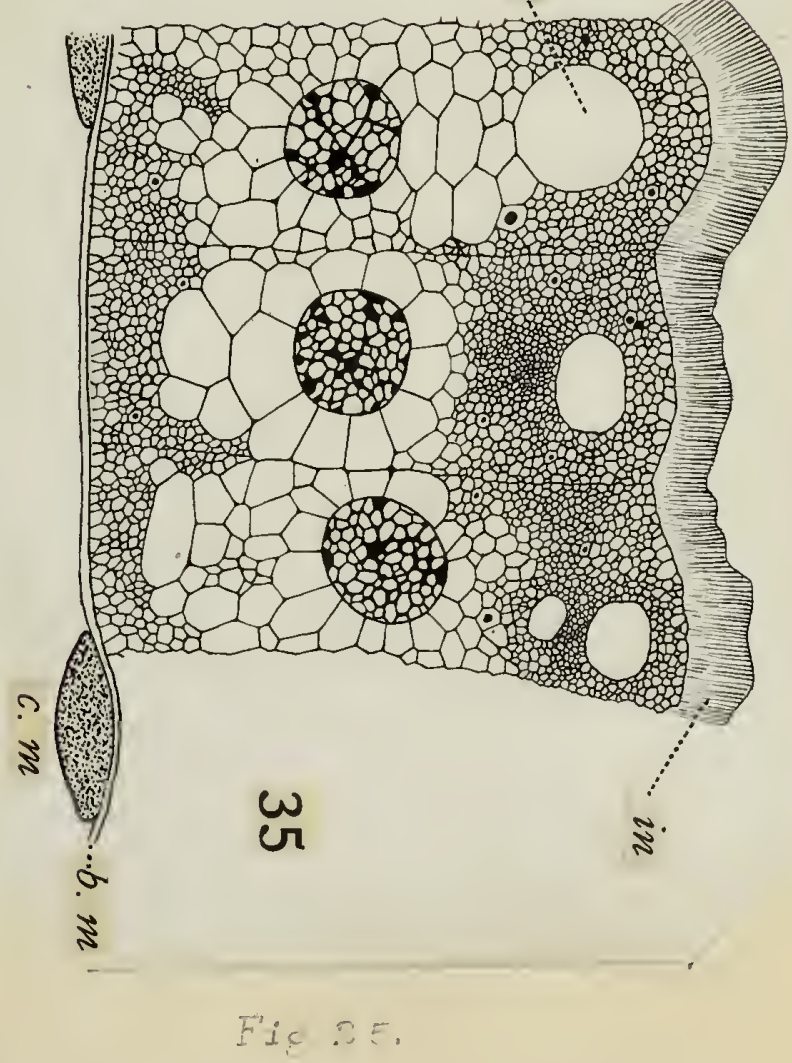



- Thing

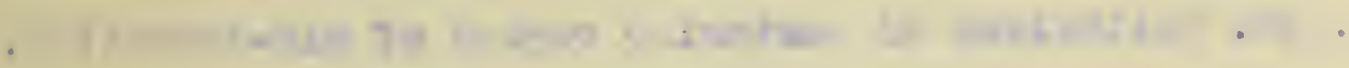


$4^{6} \quad$ Plate XI.

Fic. ส3. Epithelium of posterion recien of mid-intestine. 


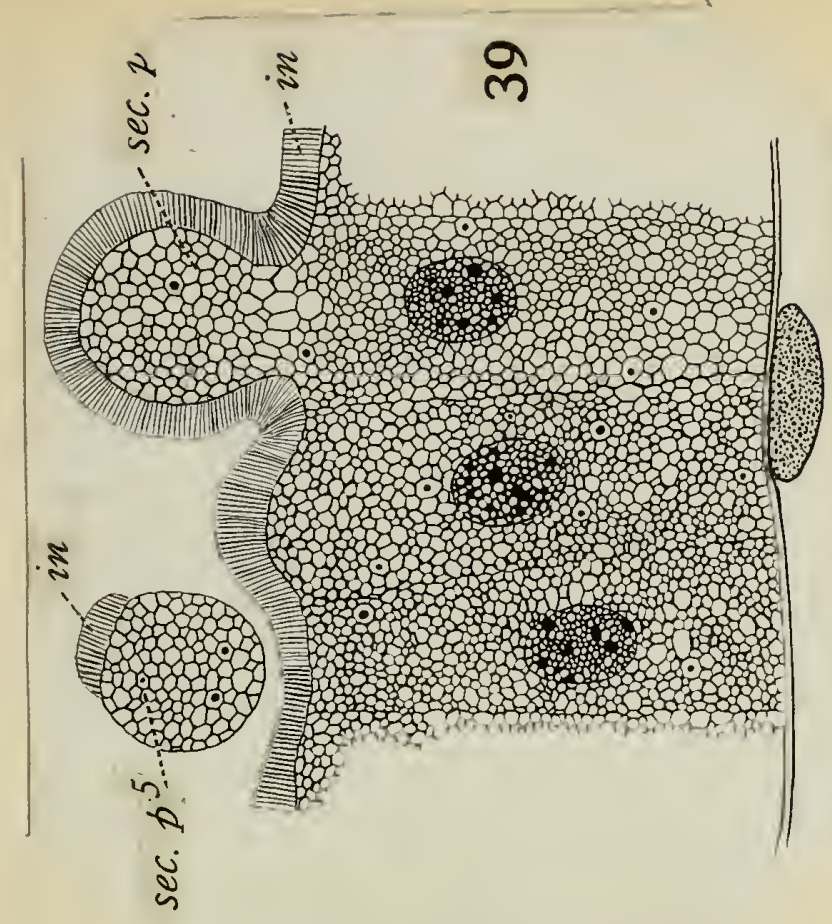

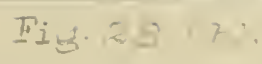

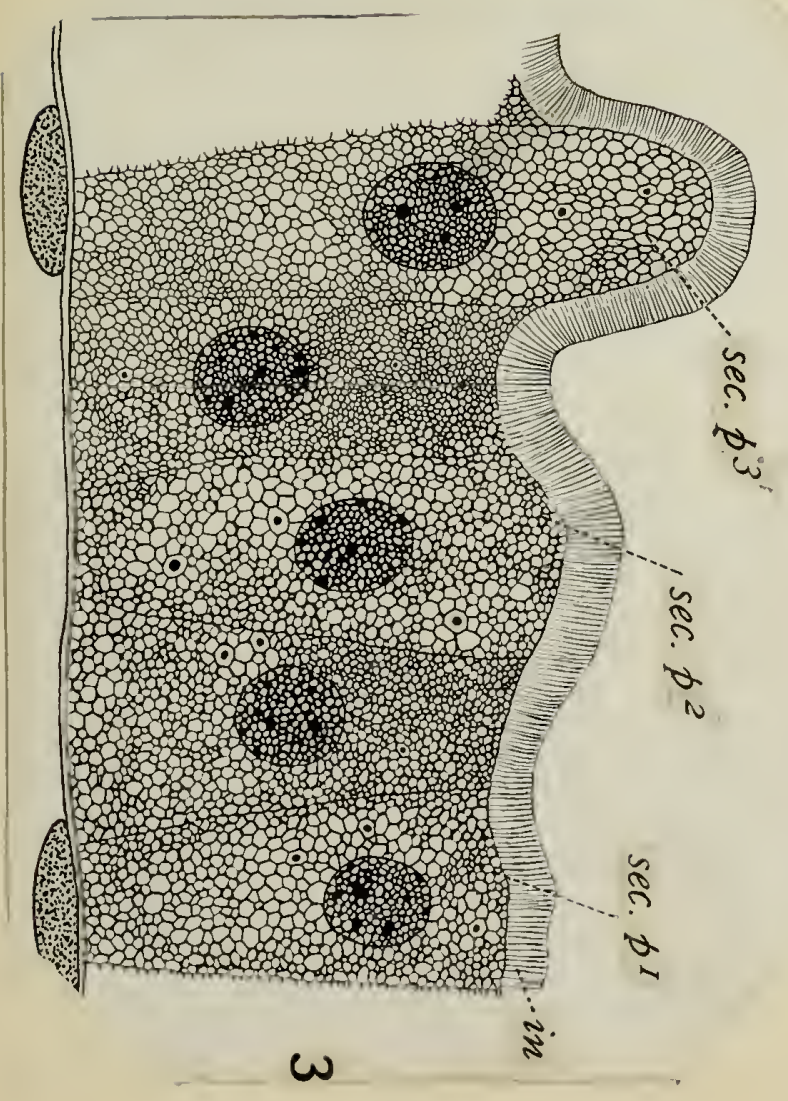

Fig. 08 (a). 




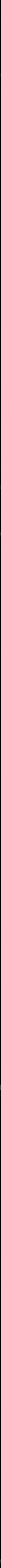

